\title{
Luiz Nunes e o projeto de instituições de saúde em Pernambuco
}

\author{
Luiz Nunes and the plan \\ for health institutions in \\ Pernambuco
}

\section{Cecilia Ribeiro}

'Pós-doutoranda, Programa de Pós-graduação em Desenvolvimento Urbano/Universidade Federal de Pernambuco. Recife - PE - Brasil

orcid.org/0000-0001-8355-2860

ceciliaribeiropereira@gmail.com
RIBEIRO, Cecilia. Luiz Nunes e o projeto de instituições de saúde em Pernambuco. História, Ciências, Saúde-Manguinhos, Rio de Janeiro, v.26, n.2, abr.-jun. 2019, p.593-620.

Resumo

Em Pernambuco, durante a gestão do governador Carlos Lima Cavalcanti (1930-1937), o arquiteto Luiz Nunes e sua equipe conseguiram realizar, em curto espaço de tempo, de 1934 a 1937, uma série de projetos de edifícios públicos notáveis. Neste artigo, são analisados os projetos da Escola para Anormais e do Hospital da Brigada Militar, que exemplificam a estreita relação entre o saber médico, a arquitetura moderna e a política do governo estadual, além de serem objetos pouco explorados em estudos acadêmicos. As fontes principais da pesquisa foram os arquivos dos jornais Diário da Manhã, Diário de Pernambuco e o conjunto de projetos de arquitetura levantado no Arquivo Público Jordão Emerenciano.

Palavras-chave: Luiz Nunes (19091937); arquitetura moderna; Escola para Anormais; Hospital da Brigada Militar.

\section{Abstract}

During Pernambuco governor Carlos Lima Cavalcanti's term (1930-1937), the architect Luiz Nunes and his team were able to produce a series of plans for notable public buildings in the short period of time spanning 1934 to 1937. This article analyzes plans for the School for Abnormal Children and the Military Brigade Hospital, which exemplify the close relationship between medical knowledge, modern architecture, and state government policy and have not yet been examined in detail in academic studies. The main sources were the archives of the Diário da Manhã and Diário de Pernambuco newspapers, as well as the group of architectural plans in the Jordão Emerenciano Public Archive.

Keywords: Luiz Nunes (1909-1937); modern architecture; School for Abnormal Children; Military Brigade Hospital. 
$\mathrm{E}^{1}$ m Pernambuco, durante a gestão do governador Carlos Lima Cavalcanti (1930-1937),

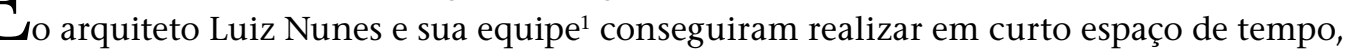
de 1934 a 1937, uma série de projetos de edifícios públicos notáveis pela sua modernidade, que ia da concepção de sua estrutura, forma e espaços funcionais à organização do canteiro de obras e à construção. Esse acontecimento foi destacado por Melo (2000) por evidenciar o papel social do arquiteto, referenciado no livro Quando o moderno não era um estilo e sim uma causa, de Anatole Kopp (1990) ${ }^{2}$ e citado por Marques e Naslavsky (2011, p.1) como sendo um acontecimento pioneiro na arquitetura moderna brasileira: "Cícero Dias viu o mundo nascer no Recife e assim o pintou. Nós vimos o modernismo nascer... e foi no Recife, como bem deu-lhe à luz Luiz Nunes".

Desses projetos, destacam-se os das instituições de assistência à saúde, como: hospitaisgerais (Hospital da Brigada Militar, Hospital de Escada); hospitais-colônia (Leprosário da Mirueira e Colônia de Alienados de Barreiros); instituições de saúde e assistência social (Usina Higienizadora de Leite, Casa da Criança e Escola para Anormais ou Escola de Débeis Mentais); além do Pavilhão para Verificação de Óbitos, anexo da Faculdade de Medicina. Esses projetos foram concebidos quando Nunes foi diretor da Seção Técnica de Engenharia e Arquitetura, da Secretaria de Viação e Obras Públicas, em 1934 e, após 1935, quando esteve à frente da recém-criada Diretoria de Arquitetura e Construções (DAC), que, em 1936, passou a ser denominada Diretoria de Arquitetura e Urbanismo (DAU).

A Santa Casa de Misericórdia detinha o controle dos serviços de saúde oferecidos no estado no século XIX, como o Hospital de Lázaros, a Casa dos Expostos, o Hospital Pedro II, o Asilo de Mendicidade, o Hospício de Alienados, o Instituto Pasteur e o Hospital de Santa Águeda, embora houvesse algumas exceções, como o Hospital do Exército (ligado a uma corporação, mas de propriedade do estado) e o Hospital Português (de propriedade de uma sociedade beneficente). Até 1934, ano da chegada de Luiz Nunes em Pernambuco, surgiram ainda, no Recife, o Hospital Centenário e a Faculdade de Medicina, ambos projetos de Giácomo Palumbo, o Hospital Infantil Manoel de Almeida, a Maternidade do Derby e o Departamento de Assistência e Saúde, sendo este o único que era de propriedade e administrado pelo estado, abrigando em seu edifício outras instituições, como o Serviço de Pronto-socorro. ${ }^{3}$

Foi a partir da atuação do médico Amaury de Medeiros no recém-criado Departamento de Saúde e Assistência, durante o governo de Sérgio Loreto (1922-1926), ${ }^{4}$ que foi iniciada uma participação maior do estado na prestação de serviços de saúde, no controle de suas atividades e na concepção de seus espaços. Na sua gestão, após inspeção nas instituições que prestavam serviços de assistência médica e averiguação de suas condições de funcionamento e de recursos e dívidas, foi constatada a necessidade de intervenção em algumas instituições. Assim, a Roda da Casa dos Expostos foi extinta, e a administração do Instituto Pasteur foi requerida pelo estado, juntamente com a do Hospício de Alienados e do Hospital de Santa Águeda, que foram reformados e passaram a ser denominados Hospital de Doenças Mentais e Nervosas e Hospital Oswaldo Cruz, respectivamente. Também foi estabelecido que o estado fiscalizaria as instituições de assistência à saúde, por meio do Departamento de Saúde e Assistência, que também faria algumas exigências "para o funcionamento de tais estabelecimentos, além das estatuídas, de um modo 
geral, nos regulamentos sanitários" (Medeiros, 1926, p.452-453). Dessas exigências, destaca-se o foco dado aos nosocômios com mais de cem leitos, que deveriam ter um laboratório "para a realização de exames químicos, microscópicos, microbiológicos, histo e anatomopatológico, necessários à elucidação diagnóstica dos doentes a eles recolhidos"; um laboratório de manipulação farmacêutica; "plantão médico, noturno"; serviço sanitário completo; salas assépticas e toda aparelhagem para a realização de operações (cirurgias); ambulatório. Além do que, as "instituições de assistência privada" deveriam submeter os seus projetos ao Departamento de Saúde e Assistência, que deveria emitir parecer sobre o projeto e a sua localização (p.452-453).

A atuação de Amaury de Medeiros (1926, p.415) foi além, chegando a propagar e a defender o estilo neocolonial para os edifícios da saúde, considerado "mais de acordo com o nosso clima, mais simples, mais risonho e mais barato". Esse gosto foi seguido em edifícios da saúde construídos ou reformados entre os anos 1920 e 1930, como os novos pavilhões do Hospital Oswaldo Cruz e do Hospital de Doenças Nervosas e Mentais.

As iniciativas ocorridas durante o governo de Sérgio Loreto foram importantes para tornar o contexto favorável e receptivo a uma intervenção maior do estado na criação de instituições de saúde, do seu projeto à sua construção. Aliado a isso, também estava o empenho na concepção dos projetos institucionais assumido por Carlos de Lima Cavalcanti em 1934, quando se preparava para a eleição do ano seguinte, em que seria legitimado no cargo. Esse fato coincidiu com a chegada ao Recife de Luiz Nunes, formado no ano anterior pela Escola Nacional de Belas Artes do Rio de Janeiro.

O caráter modernizador que assumiu o governo de Carlos de Lima Cavalcanti, primeiro como interventor nomeado por Getúlio Vargas, de 1930 a 1935, depois como governador eleito pela Assembleia Legislativa, de 1935 até 1937,, estava, inclusive, diretamente ligado à política adotada pelo governo federal. Nela, visava-se dotar o Estado de um aparato técnico-burocrático, com estímulo à industrialização e à urbanização. Para isso, foram criadas instituições de suporte aos trabalhadores, que surgiam aliadas ao discurso da arquitetura moderna.

No âmbito das políticas públicas de saúde, a novidade estava na criação do Ministério da Educação e Saúde Pública, em 1930, que passou a sistematizar diretrizes no trato da saúde pública. Assim, o governo Vargas, além de manter a política sanitária, iniciada no período da Primeira República, entre as décadas de 1910 e 1920, pelo Departamento Nacional de Saúde sob a égide do Ministério do Interior, passou a intervir nos espaços urbanos. Segundo Amora (2006, p.48), referenciando-se em Vigiar e punir, de Michel Foucault, "essa concepção estava presente na formulação e no incremento de políticas públicas, bem como na promoção de uma grande ação normativa sobre a sociedade, tendo como objetivo uma maior homogeneização do corpus da nação para gerar um Povo-Nação".

O discurso da arquitetura moderna já circulava no país de forma dispersa desde a década de 1920. No entanto, com a reforma no currículo e no quadro de professores da tradicional Escola Nacional de Belas Artes no Rio de Janeiro, em 1931, promovida pelo seu então diretor, Lúcio Costa, que incluía Gregori Warchavchik e Affonso Eduardo Reidy, foi dado início à formação de arquitetos dentro dos preceitos da arquitetura moderna, mesmo considerando a demissão do seu diretor no mesmo ano. 
A recepção à arquitetura moderna no meio técnico, segundo Marques e Naslavsky (2011), já estava antecipada pela circulação das ideias de Le Corbusier, que tinha visitado o Brasil em 1929. No Recife, duas conferências suas foram publicadas no jornal A Província, e a tese do médico pernambucano Aluízio Bezerra Coutinho, O problema da habitação higiênica nos países quentes em face da "arquitetura viva", defendida em 1930, também fazia referência às suas ideias.

O primeiro registro da presença de Nunes nos jornais do Recife é de 17 de maio de 1934, quando foi citada a sua participação na comissão de avaliação das propostas das empresas de engenharia que concorriam ao direito de construir a Usina Higienizadora de Leite, como será detalhado mais adiante. No entanto, o registro de sua contratação pelo estado aconteceu, segundo Marques e Naslavsky (2011, p.3), "em julho de 1934 para chefiar o Setor de Obras Públicas do Estado de Pernambuco". Assim, somente após mais de um ano trabalhando nos projetos institucionais de obras do governo é que foi criada a Diretoria de Arquitetura e Construção (DAC), pelo decreto n.4, de 29 de agosto de $1935 .{ }^{6}$ Até então, já haviam sido concebidos edifícios para novas instituições ou para órgãos que ocupavam edifícios alugados, como explica o trecho da entrevista dada por Lima Cavalcanti no início da sua segunda gestão:

Está em estudos a sistematização da construção dos edificios para o serviço público, de modo a realizá-la com o máximo de economia e dentro das mais modernas exigências técnicas.

Para isto conseguir, havia já o governo criado o Escritório Técnico de Engenharia e Arquitetura que, com cinco meses de trabalho apenas, já conta em seu acervo com vários projetos de relevo como sejam a Usina Higienizadora de Leite, Casa da Criança (ambulatório para crianças até 4 anos), Escola de Débeis Mentais, Hospital da Brigada Militar e Postos Policiais no Recife além de outros projetos em elaboração como sejam:

Escola Agrícola de Menores Abandonados, com capacidade para 250 alunos, Mercado de Peixe, Manicômio Judiciário, Secretaria de Viação e Obras Públicas, etc. Os projetos orçados montam em cerca de 3.000 contos.

Com a nova organização, este Escritório de Engenharia e Arquitetura tem suas funções ampliadas e fica com possibilidade de imprimir, aos serviços que temos em mente, levar avante uma feição eminentemente técnica, para o que será dotado de todos os elementos quer quanto ao pessoal, quer quanto ao material, que se fizer necessário (Pernambuco..., 17 abr. 1935). ${ }^{7}$

Destaca-se ainda que, no período que antecedeu a criação da DAC, os projetos de Luiz Nunes e sua equipe fizeram parte da representação pernambucana na Exposição Farroupilha, em Porto Alegre, organizada pelo secretário de Agricultura Paulo Carneiro, cientista conhecido posteriormente pela sua atuação na Organização das Nações Unidas para a Educação, a Ciência e a Cultura (Unesco) e que teve uma breve passagem por Pernambuco. O engenheiro Joaquim Cardozo, que trabalhou com Nunes durante todo o período em que atuou no Recife, ${ }^{8}$ foi o representante da sua equipe junto à organização da exposição. Vale destacar que, depois da criação da DAC, houve uma breve interrupção de seus trabalhos em 1935, por motivos políticos, retomados em 1936, quando a diretoria passou a ser chamada de Diretoria de Arquitetura e Urbanismo (DAU), e durou até a diretoria sofrer uma mudança em sua denominação e orientação, em 28 de dezembro de $1937 .{ }^{9}$

Das suas obras, destacam-se, nos tópicos a seguir, os projetos e obras iniciados ainda em 1934, como a Escola para Anormais e o Hospital da Brigada Militar, que representam 
de maneira exemplar os projetos de saúde elaborados no ano da chegada de Nunes ao Recife. Além de evidenciar estreita relação entre o saber médico, a arquitetura moderna e a política do governo estadual, esses dois projetos foram objetos pouco explorados em estudos acadêmicos. As fontes principais da pesquisa são os jornais Diário da Manhã, que pertencia à família do governador Carlos de Lima Cavalcanti e, portanto, fazia extensa divulgação das ações de seu governo, e o Diário de Pernambuco, jornal de oposição, e o conjunto de projetos de arquitetura levantado no Arquivo Público Jordão Emerenciano. ${ }^{10}$

\section{Assistência social, saúde e arquitetura}

O primeiro projeto de Luiz Nunes em Pernambuco foi o da Usina Higienizadora de Leite, em 1934. No mesmo ano, foram apresentados os projetos da Casa da Criança e do Hospital da Brigada Militar (em agosto) e da Escola para Anormais (em novembro).

A Usina Higienizadora de Leite, criada a partir do decreto n.160, de 12 de novembro de 1932, já contava com um projeto de arquitetura desde 1933, de autoria do engenheiroarquiteto Heitor Maia Filho, então funcionário da Prefeitura do Recife, que tinha bastante prestígio junto ao governo estadual, tendo sido um dos fundadores da Escola de Belas Artes do Recife, em 1932.

Para a construção de obras públicas era uma prática, nesse momento, a realização de concurso entre empresas de engenharia. Com a realização de um concurso para a escolha da empresa que iria construir o edifício em maio de 1934, uma delas apresentou "uma variante" que corrigia "falhas" de projeto, o que, segundo a comissão que julgou as propostas, formada por Nunes e pelos engenheiros José Alexandre Teixeira de Mello e João Pereira Borges, ${ }^{11}$ tornava desigual a disputa, o que fez com que o concurso fosse anulado. ${ }^{12}$ Em referência ao ocorrido, o jornal Diário da Manhã não citou qual teria sido a falha a ser resolvida, mas relata a necessidade de um novo projeto "oficial" (Vida..., 17 maio 1934 , 20 nov. 1934; A construção..., 21 jun. 1934). Luiz Nunes ficou responsável pela elaboração do novo projeto, e outro concurso foi realizado. A empresa vencedora foi Brandão \& Magalhães.

A difusão da ideia do leite "como um alimento importante para a saúde" (Diário..., 22 jun. 1934) era enfatizada pelo médico Octavio de Freitas desde a epidemia de influenza (gripe espanhola), ocorrida no Recife, em 1918. A criação da usina estava entre os feitos de Carlos de Lima Cavalcanti em prol da saúde da população, além de promover a organização e o melhoramento da produção e produtividade pecuária, atendendo a uma demanda do setor econômico. Assim, ao mesmo tempo que eram destacados os benefícios para a saúde, em matérias de jornal, em citações como: "O leite nutre e desenvolve a criança, alimenta o enfermo, levanta as forças do convalescente, conserva a saúde do adulto e rejuvenesce o velho", eram também elencados os perigos que um leite contaminado poderia trazer, justificando, assim, a criação da usina: "O leite do Recife é uma bebida que inspira os mais justos receios, porque este leite traz o micróbio, o micróbio causa a doença e a doença é o estado intermediário entre a vida e a morte", dessa maneira, "para obter-se um leite puro fazse mister: vaca sã, ordenha asséptica, vasilhame limpo, fechamento hermético e transporte adequado", tais citações, de Armando Maia em conferência pronunciada na Sociedade de Medicina, foram publicadas no Diário da Manhã (Diário..., 22 jun. 1934). 
Segundo Alecrim e Amorim (2010, p.4), o programa do edifício do Instituto de Zootecnia, Leite e Derivados - Usina Higienizadora de Leite, se distribuía em dois pavimentos, sendo o térreo destinado à usina de leite e o pavimento superior ao instituto de zootecnia, sendo que, como novidade,

é relevante destacar que o plano linear e modular proposto por Nunes é congruente com seu interesse de criar um plano livre capaz de se ajustar às mudanças programáticas, em particular no pavimento superior. A distribuição uniforme de aberturas de mesma dimensão tem o claro objetivo de permitir a alteração da planta sem comprometer a composição e as necessárias condições de iluminação e aeração dos ambientes.

Já o projeto da Casa da Criança foi iniciativa da Liga Pernambucana Contra a Mortalidade Infantil, que era uma instituição subvencionada pelo estado, regida pela lei n.2.023, de 25 de setembro de 1929, e gerida pelo diretor do Departamento de Saúde Pública. ${ }^{13}$ Antes da sua construção, a Liga já havia inaugurado o preventório Bruno Veloso, para "débeis escolares", em Boa Viagem; creches na "Torre, Várzea e Moreno, junto aos principais núcleos industriais de Pernambuco, onde o filho da mulher operária recebe aleitamento, em horas determinadas" e lactários em algumas cidades do estado (A casa..., 9 ago. 1934).

A Casa da Criança deveria atender crianças de até 4 anos, incluídas as que eram encaminhadas pelos quatro centros de saúde então existentes no Recife. A motivação para a sua construção era o alto índice de mortalidade infantil, o que era associado à saúde das mães e à qualidade da alimentação recebida, e, por conta disso, esse seria o foco do seu atendimento. O médico pediatra Armando Meira Lins destacou, inclusive, o "princípio educativo" da obra, em sua inauguração:

Senhores, três grandes flagelos devastam nossos berços: a falta de alimentação natural e suficiente, a sífilis congênita e a tuberculose! Alimentar bem as nossas crianças é básico, livrá-las da sífilis degeneradora é imperioso, como arrancá-las das garras da tuberculose é para nós uma questão de vida ou de morte. Elas se infeccionam nas míseras choupanas, úmidas e insalubres, na mais criminosa das promiscuidades com os parentes; nas escolas; nas oficinas e nas ruas.

Crianças de meu Estado e crianças do Brasil! Que fique não um monumento mudo e frio o edifício que neste momento levantamos, mas que com ele se forme uma mentalidade nova e combativa - inexpugnável fortaleza - contra a qual sejam impotentes as armas da ignorância e da rotina que têm sido vossa desgraça! (Lançamento..., 17 ago. 1934).

O terreno para a construção da Casa da Criança, de 20x50 metros, adquirido pela Liga, ficava próximo do Departamento de Saúde Pública. Da apresentação do seu projeto e lançamento da pedra fundamental, em 15 de agosto de 1934, até a sua inauguração, em 24 de outubro de 1936, foram dois anos. O programa arquitetônico se distribuía em dois pavimentos, o térreo, com: farmácia, laboratório, banheiros, cinco consultórios (sendo três para atendimento geral e dois especializados, um para olhos e o outro para garganta), e diatérmica (fisioterapia), além de uma cozinha dietética, e o pavimento superior, com: diretoria e biblioteca, almoxarifado, tesouraria, secretaria, sala de conferência (para as mães), teatro e solário. ${ }^{14}$ Enquanto a solução arquitetônica, de volumetria e organização espacial, 
ainda não imprimia as características marcantes da obra de Nunes no Recife, destaca-se a preocupação com a cozinha dietética:

Neste prédio, continua o dr. Lessa de Andrade [diretor do Departamento de Saúde Pública e da Liga Contra a Mortalidade Infantil], instalará a Liga uma moderna cozinha dietética, que constituirá uma das mais seguras armas de combate à mortalidade infantil sabido como é que os distúrbios digestivos oriundos de uma alimentação inadequada são a fonte, na maioria dos casos, das doenças nas crianças. A Liga vai, assim, ao encontro da solução deste problema, fornecendo diariamente a cada lactente, por intermédio da sua cozinha dietética, não o leite apenas, mas a alimentação que melhor convém para o seu desenvolvimento normal" (Liga Pernambucana..., 10 jun. 1936).

Foi com a Escola para Anormais que Nunes deu início à sistematização do seu processo de trabalho, da concepção do projeto arquitetônico e estrutural à construção da obra, levando em conta, para isso, os recursos limitados de que dispunha, o que estimulou uma inovação no uso de materiais e na organização de seu canteiro de obras. A ideia para a construção da escola partiu do médico Ulysses Pernambucano (1892-1943), então diretor do Serviço de Assistência a Psicopatas, criado em 1931. O trabalho de Pernambucano com relação ao tratamento de crianças com deficiência teve como ponto de partida a sua tese, pioneira no Brasil, Classificação das crianças anormais: a parada do desenvolvimento intelectual e suas formas: a instabilidade e a astenia mental, defendida em 1918, no concurso para professor da Escola Normal Oficial do Estado de Pernambuco. Após assumir a direção da escola, propôs, em 1923, ao então governador Sergio Loreto, uma reforma que incluía a criação de uma escola para crianças "anormais", formalizada dois anos depois, mas que na prática funcionava como uma disciplina dentro da Escola Normal. ${ }^{15}$

A designação "normal" nesse momento era usada tanto como referência à formação escolar como para indicar o estado de saúde que se contrapunha ao patológico; assim, "o ensino primário serve, portanto, na realidade, de filtro e de referência a esses fenômenos de retardo mental" (Foucault, 1996, p.270). Os atrasos no desenvolvimento de crianças eram medidos em testes de aptidão realizados pelo Instituto de Psicologia da Assistência a Psicopatas, que em 1936 apresentou o seguinte quadro: das “628 crianças que frequentavam as escolas do $5^{\circ}$ distrito escolar encontra[ram] 2,70\% de imbecis, 19,10\% de débeis mentais e 8,75\% de atrasados" (Inicia-se..., 24 maio 1936).

Após a criação da Liga de Higiene Mental (LHM) de Pernambuco, ${ }^{16} \mathrm{em} \mathrm{1933,} \mathrm{foi} \mathrm{iniciada}$ a campanha ${ }^{17}$ para a construção da escola, junto à prefeitura e ao estado, aos comerciantes, às escolas (onde foi instituído o Dia do Tostão a ser doado pelos alunos), às "senhoras" da sociedade e nos jornais da cidade (Liga Pernambucana..., 5 jul. 1934; Liga de Higiene..., 16 out. 1934; O dia..., 20 dez. 1934). A ideia era que a escola promovesse um tratamento médico-pedagógico das crianças, inclusive com o internamento dos "que não têm família ou apresentam perturbações neuropsiquiátricas que exigem o internamento" (Pela educação..., 5 dez. 1934). Destaca-se que muitas crianças ocupavam leitos do Hospital de Doenças Nervosas e Mentais (atual Hospital Ulysses Pernambucano), onde eram "precariamente isolados dos adultos, sem possibilidade de receberem o tratamento médico-pedagógico indispensável" (Pela educação..., 5 dez. 1934). 
A assistência social a uma infância em risco era uma ideia difundida desde o final do século XIX na França, onde "a noção de perigo se torna a noção necessária para converter um fato de assistência num fenômeno de proteção e para permitir que, nesse momento, os que são encarregados da assistência o aceitem" (Foucault, 1996, p.278). O tratamento das crianças não era só uma questão médica e educativa, era também moral, tal como argumentou o desembargador João Aureliano Corrêa de Araújo, presidente da LHM, em matéria de jornal em que defendia a necessidade da criação da escola como "profilaxia da criminalidade" (O dia..., 20 dez. 1934) e "fator de higiene social" (Foi ontem..., 27 dez. 1934).

Crianças anormais, crianças com inteligência apoucada, crianças com desequilíbrio afetivo, seres cuja educação nas escolas para normais é um desastre e um martírio, seres cujo abandono à própria sorte conduz quase sempre ao mesmo destino. Inadaptação. Vagabundagem. Roubo. Um eterno errar pelas mãos de novos e novos professores. Um eterno errar pelos consultórios dos especialistas em voga. E mais tarde a triste faculdade de escolher: ou delinquência ou parasitismo (Falcão, 24 nov. 1934).

A proposta da escola visava atender também à necessidade de formação do saber médico, que se daria por meio de pesquisas e estudos que promoveria em suas dependências, e o seu projeto de arquitetura seria um aliado, sendo considerado "um verdadeiro hospital-escola" (Uma visita..., 17 set. 1935), "um centro de pesquisas e de estudos, de métodos médicopedagógicos para tratamento e educação de anormais, formando ao mesmo tempo médicos e professores especializados" (Inicia-se..., 24 maio 1936).

O terreno adquirido para a construção da escola ficava em frente ao Hospital de Doenças Nervosas e Mentais, na antiga estrada de Água Fria (trecho atualmente chamado de rua Cônego Barata). Era irregular e media sessenta metros de frente e cem metros de profundidade, aproximadamente (Figura 1). A sua pedra fundamental foi colocada no dia 25 de dezembro de 1934, mas o seu projeto já havia sido apresentado em 1 de novembro do mesmo ano. Sua extensa área permitia futuras ampliações de suas instalações.

Figura 1: Projeto da Escola para Anormais

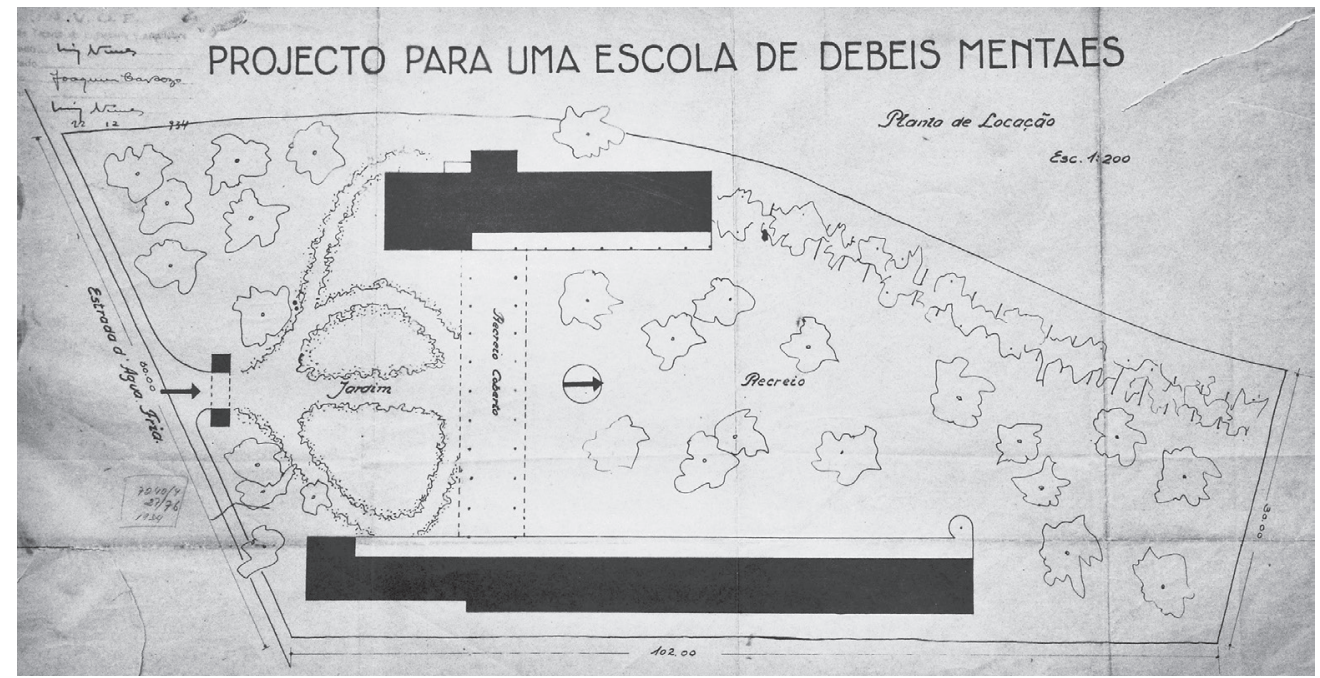

Fonte: Arquivo Público Jordão Emerenciano, Recife. 
Para a construção da escola, não foi selecionada e contratada uma empresa de engenharia, como era a prática, mas, diferentemente do Hospital da Brigada Militar, que foi construído pelo corpo da Brigada, como será visto no próximo tópico, Nunes ficou responsável pela construção da escola. Esse fato marcou a sua produção, pois foi o ponto de partida para a criação de um sistema de trabalho que associava o processo de concepção arquitetônica e estrutural ao de construção sob sua responsabilidade, o que não ocorreu sem conflito, tal como foi justificado:

A propósito da carta publicada pelo Jornal do Recife de ontem, a liga de Higiene Mental declara que a construção da Escola de Anormais vai ser feita por administração.

A seção técnica da Repartição de Viação e Obras Publicas e o arquiteto do Estado dr. Luiz Nunes dirigirão toda a obra sem qualquer ônus para a Liga. Dispendendo a Liga e a Caixa Escolar Ulysses Pernambucano de quantia não superior a 100 contos para a construção que está orçada em 200, muito dificilmente se encontraria construtor idôneo que se quisesse arriscar aos ônus de paralisação da obra por falta de numerário. Acresce que dirigida a construção pelo próprio arquiteto que a delineou sairá ela mais perfeita e a liga fará economia dos lucros que auferia o construtor.

Em resumo: a Escola de Anormais se vai fazer sob a direção da Repartição Técnica do Estado recentemente organizada, limitando-se as duas instituições - a Liga e a Caixa Escolar - a adquirir como vem fazendo o material por concorrência na praça e a efetuar o pagamento da mão de obra de acordo com as medições e preços aprovados pela direção da construção (Liga de Higiene..., 11 jan. 1935).

No Arquivo Público Jordão Emerenciano existem duas versões do projeto. Um conjunto de desenhos (plantas-baixas, cortes, fachadas e perspectivas) datados de dezembro de 1934 (incluindo uma planta de iluminação interna e externa) e fevereiro de 1935, referentes à primeira versão do projeto, e outros de outubro de 1935, referentes a uma segunda versão.

O projeto da escola é composto de dois blocos paralelos, ligados por uma passarela coberta, chamada de recreio coberto. Cada um dos blocos atende a uma função, sendo o bloco menor destinado às atividades de ensino e refeições, e o maior destinado à administração e aos alojamentos. A diferença entre as duas versões do projeto está no aumento da capacidade de atendimento às crianças e na ampliação do espaço para as clínicas da Faculdade de Medicina. Assim, o menor, térreo, ganhou mais um pavimento, e o bloco maior passou de dois para três pavimentos. Nas perspectivas que constam nas Figuras 2 e 3, a primeira versão do projeto. 
Figura 2: Projeto da Escola para Anormais

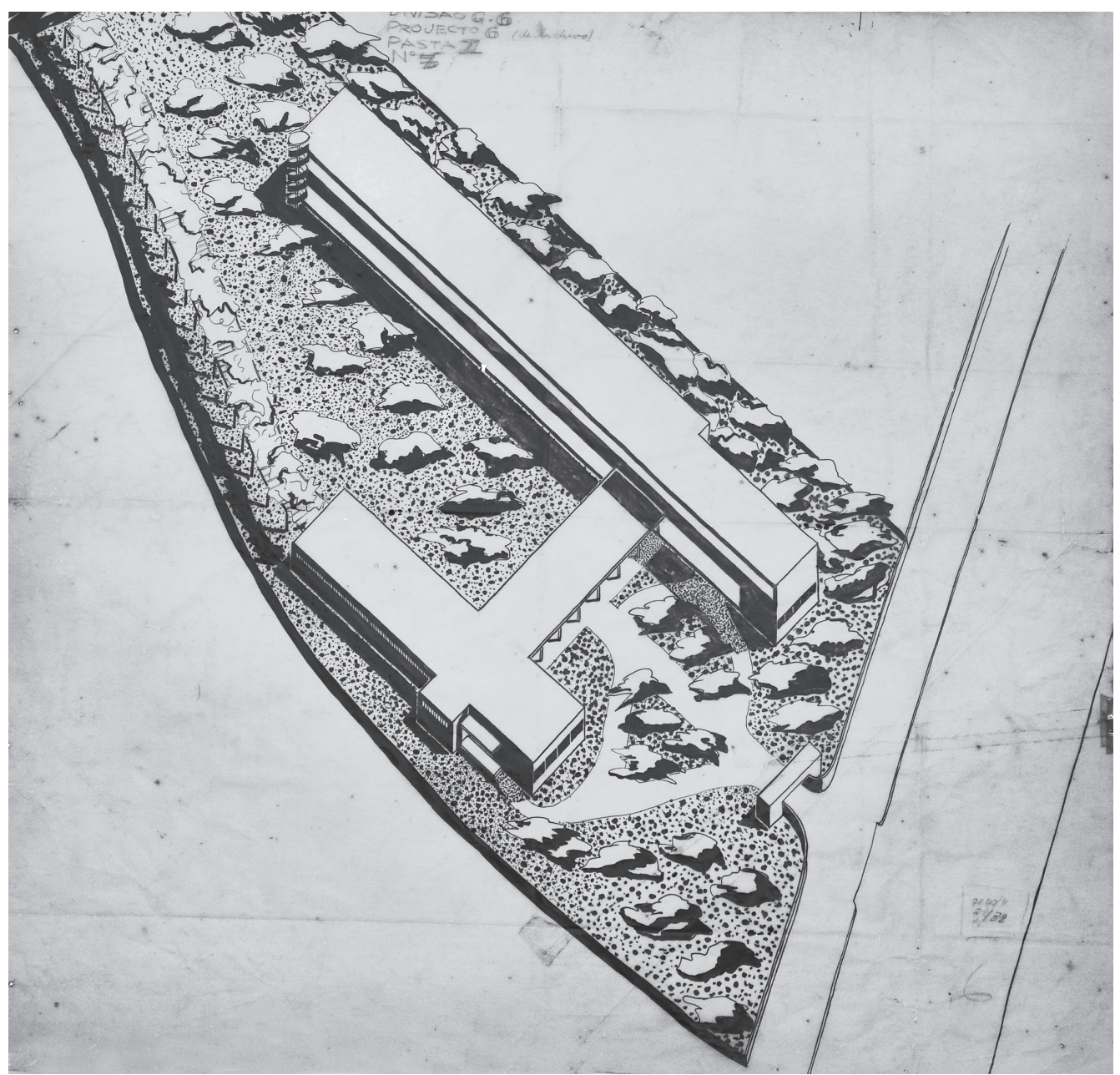

Fonte: Arquivo Público Jordão Emerenciano, Recife.

Figura 3: Projeto da Escola para Anormais

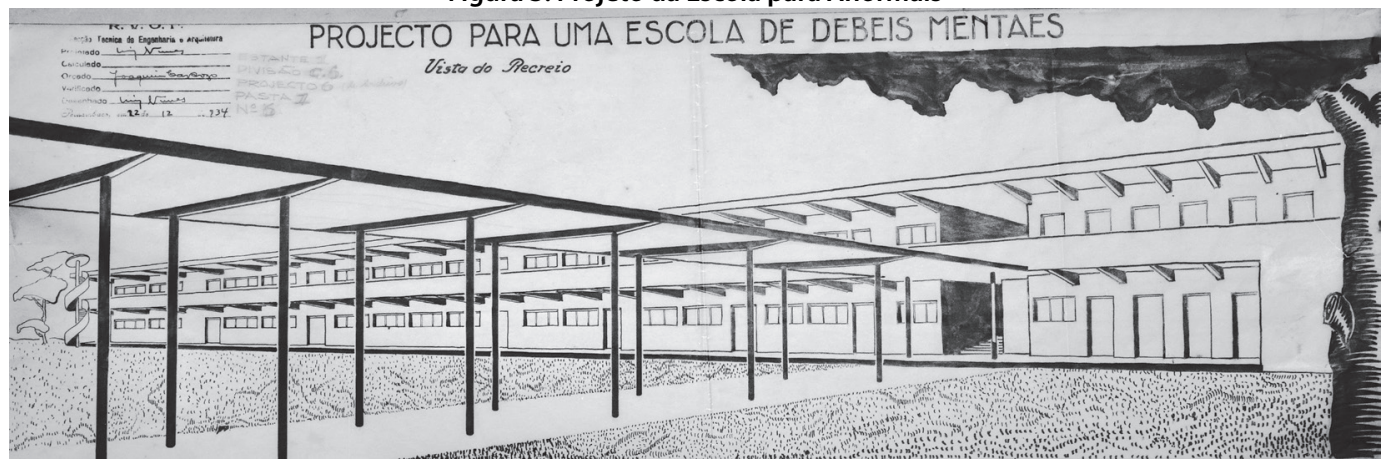

Fonte: Arquivo Público Jordão Emerenciano, Recife. 
No bloco menor constavam copa (com acesso ao exterior), dois refeitórios (para as crianças e os funcionários), área para lavatórios e bebedouros e três salas de trabalho e aula (Figura 4). Destaca-se que seria utilizada a cozinha do Hospital de Doenças Mentais, vizinho à escola, para o fornecimento das refeições. Com a mudança do projeto, foram acrescentados, além da escada, uma bateria de banheiros no térreo (Figura 5). No pavimento superior, mais três salas de trabalho e espaço para o funcionamento de duas clínicas da Faculdade de Medicina, com "anfiteatro para 75 alunos, com cabine para cinema e epidiascópio, sala de material didático, e três salas para trabalho dos professores-assistentes e internos" (Escola..., 17 set. 1935).

Figura 4: Projeto da Escola para Anormais

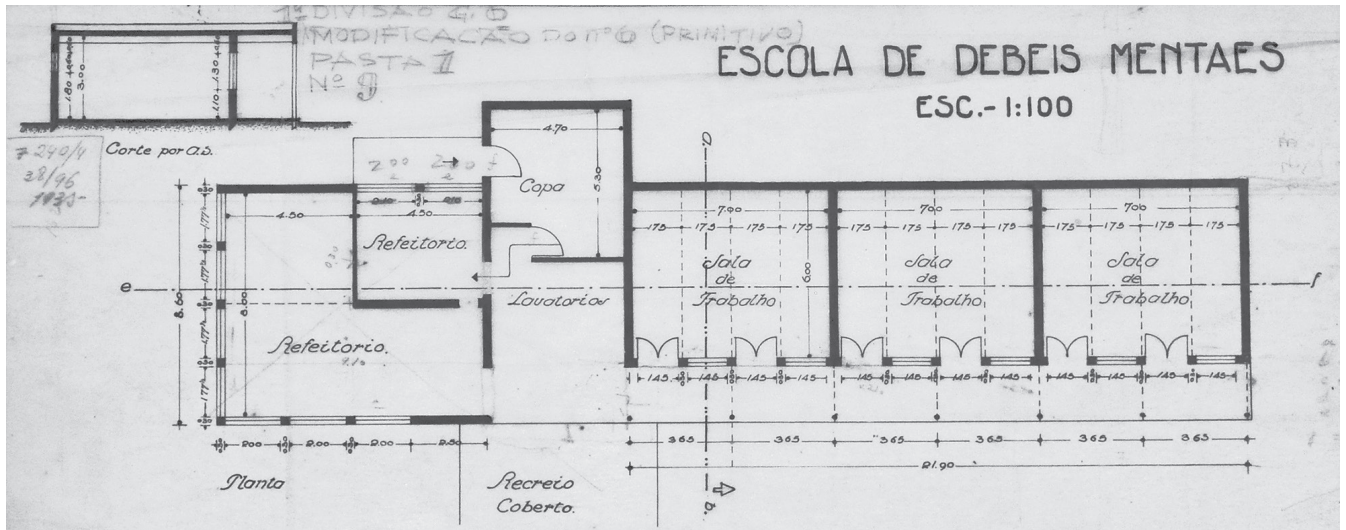

Fonte: Arquivo Público Jordão Emerenciano, Recife.

Figura 5: Projeto da Escola para Anormais

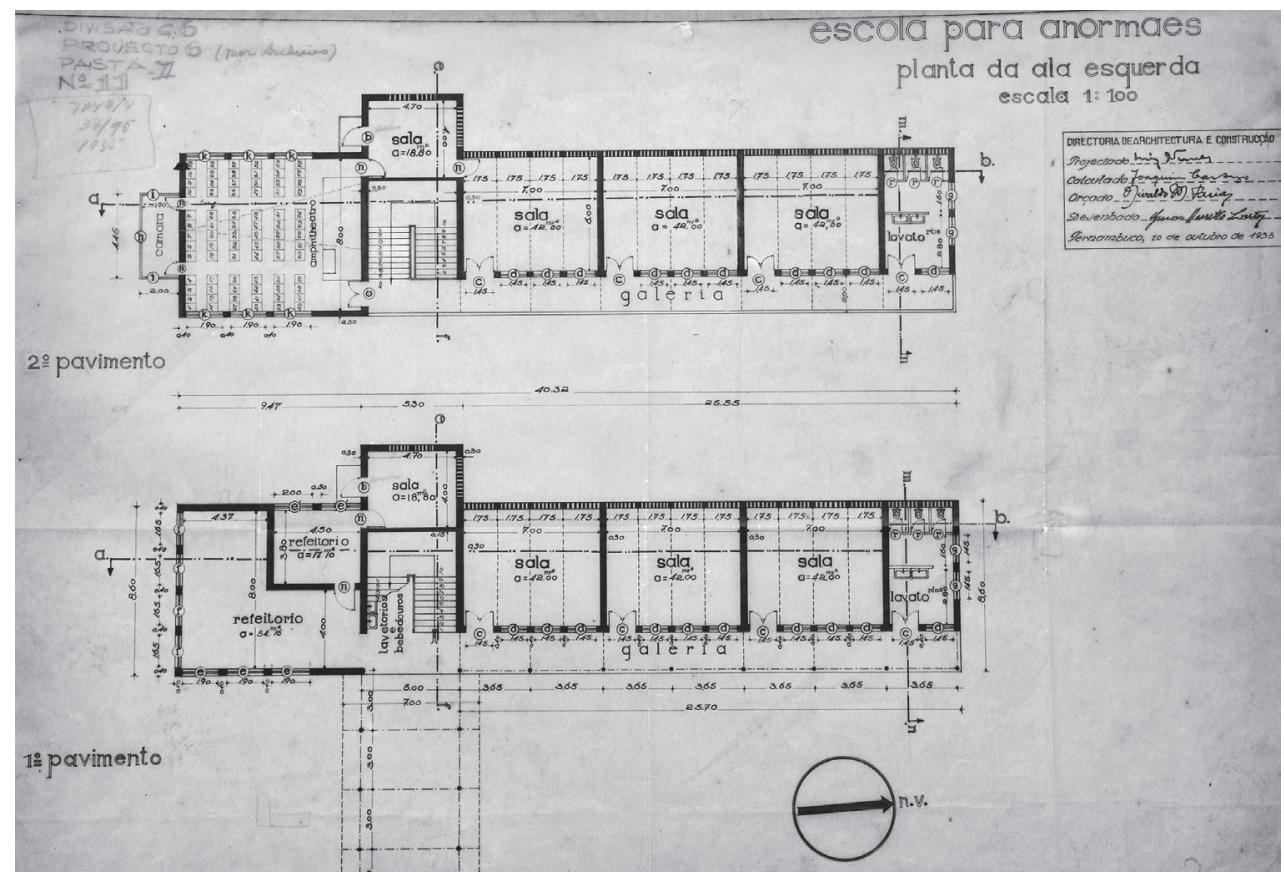

Fonte: Arquivo Público Jordão Emerenciano, Recife. 
No bloco maior, um paralepípedo de 76 metros de comprimento, com um volume cilíndrico aberto, estão dispostos, do lado direito da escada, diretoria, biblioteca, sala de médicos e banheiros; do lado esquerdo, os alojamentos das crianças, com dois dormitórios, um feminino e outro masculino, duas baterias de banheiros, uma rouparia e uma sala para vigia (na posição central do alojamento). No piso superior, constariam seis quartos e uma bateria de banheiros, além dos alojamentos das crianças, que teria seu arranjo repetido. $\mathrm{Na}$ segunda versão do projeto, esse pavimento seria duplicado (Figuras 6 e 7).

Figura 6: Projeto da Escola para Anormais

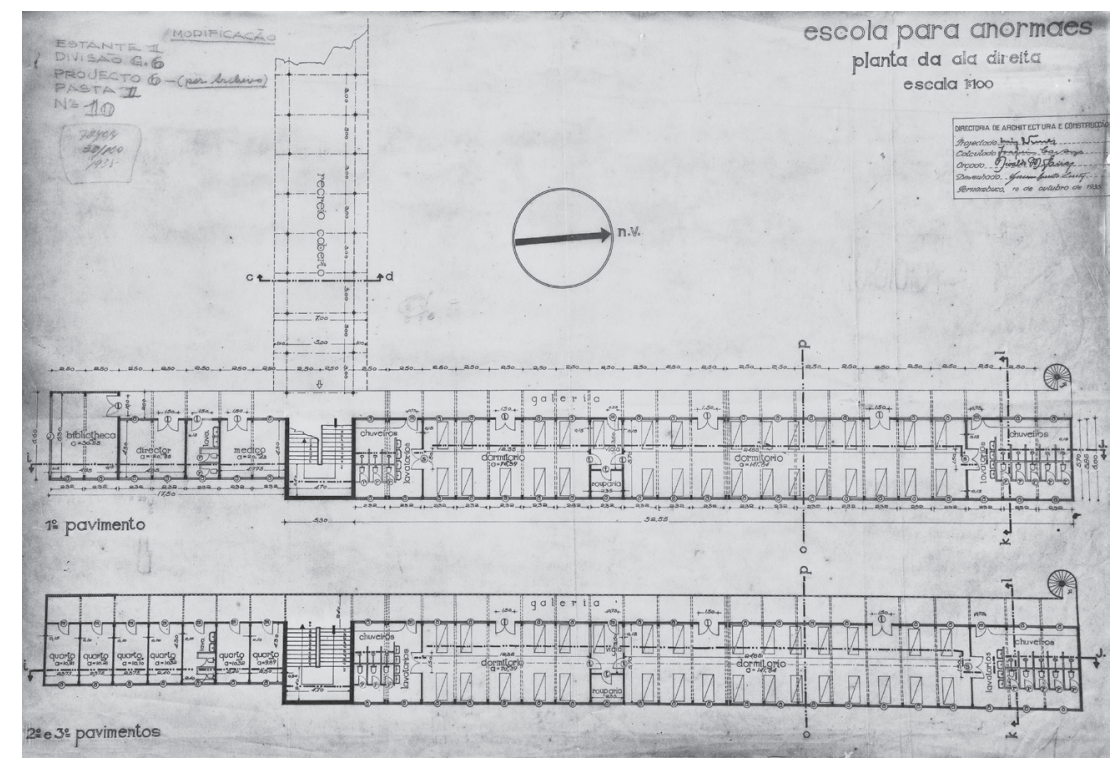

Fonte: Arquivo Público Jordão Emerenciano, Recife.

Figura 7: Projeto da Escola para Anormais

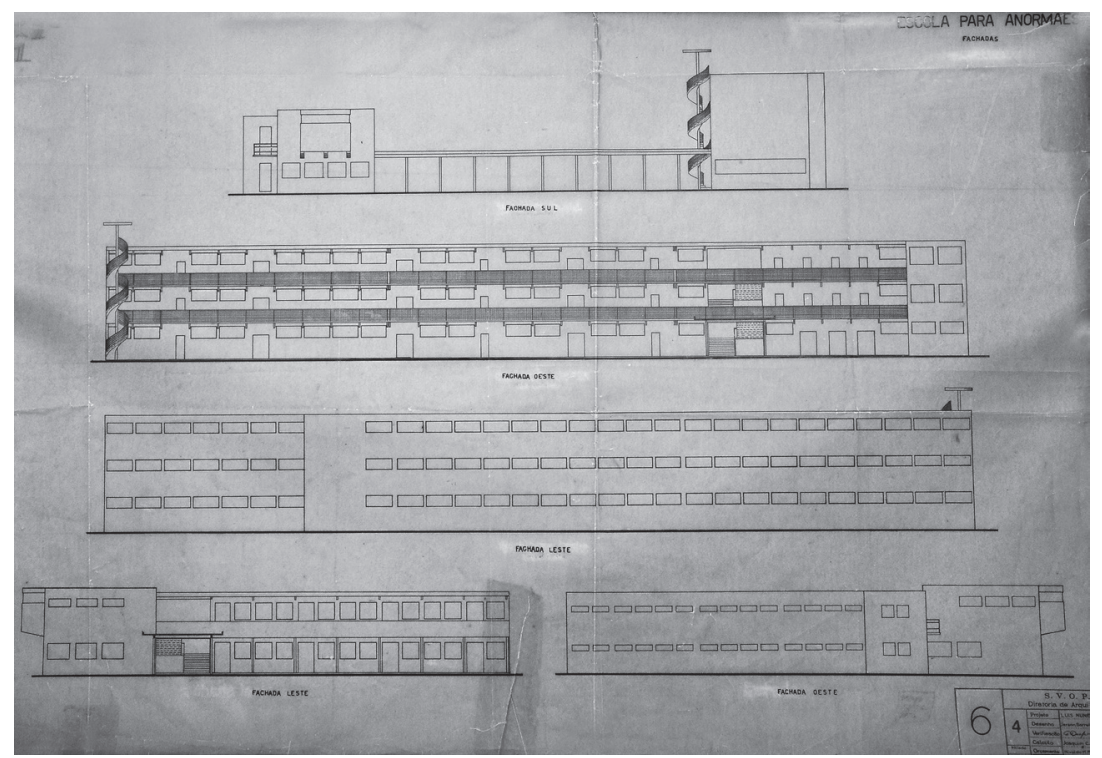

Fonte: Arquivo Público Jordão Emerenciano, Recife 
Em artigo assinado pela diretoria há uma defesa do projeto de construção da escola, tendo em vista os preceitos adotados, a orientação da construção em relação aos ventos e à insolação, o uso de materiais como o cobogó e a sistematização de sua estrutura:

Para o Diário da Manhã: divulgação da Diretoria de Arquitetura e Construção

Todo edificio tem no mínimo uma função e para satisfazê-la há uma série de circunstâncias: o local, os materiais construtivos, seus aspectos, suas possibilidades etc., etc.

A coordenação de todos estes elementos para permitir uma função, determina uma forma.

Em arquitetura a forma é sempre uma resultante.

E a beleza? A beleza é o perfeito ajustamento entre a função e a forma.

Dentro deste ponto de vista, tem a Diretoria de Arquitetura e Construção procurado realizar em Pernambuco algo que possa testemunhar a sua evolução tanto sob o aspecto técnico como também social.

O projeto foi estudado em duas alas que se desenvolvem paralelamente, ligados por um recreio coberto com $210 \mathrm{~m}^{2}$. As alas assim dispostas são francamente orientadas para o nascente. A ala direita é protegida do poente por uma galeria de circulação, na esquerda, as paredes excessivamente isoladas foram feitas com painéis multicelulares vasados no sentido transversal com furos rectangulares de 0.05.0.05. Estes blocos não permittem a entrada de sol nem de chuva, garantindo no entanto uma permanente ventilação, muito necessária neste clima. Esta disposição do edifício em duas alas paralelas permitiu também a continuidade entre o jardim tratado, o recreio coberto e o recreio comum arborizado.

O projeto em questão foi estudado para ser executado dentro de uma técnica construtiva moderna. Sua estrutura muito leve é composta de quadros rígidos num só sentido com vão de 6,00 metros. Todos os seus elementos foram uniformizados o mais possível, a fim de conseguir-se um preço de custo baixo.

A sua capacidade inicialmente é de 60 internados, reservando-se para cada um as seguintes áreas:

Nos dormitórios $-6,54 \mathrm{~m}^{2}$

Nos anfiteatros $-0,94 \mathrm{~m}^{2}$

No refeitório $-1,80 \mathrm{~m}^{2}$

Recife, 23 de novembro de 1935 (Diretoria..., 24 nov. 1935).

O cobogó, como solução de projeto para permitir a circulação de ar e a iluminação dos espaços, foi utilizado posteriormente na Caixa d'Água de Olinda e no Pavilhão de Verificação de Óbitos, duas de suas obras mais emblemáticas, projetadas no final de sua carreira.

O processo de trabalho de Nunes e sua equipe envolvia as práticas projetuais e de construção, a renovação dos métodos de trabalho, a padronização dos materiais, além do uso da estrutura independente e da preocupação com a diminuição do custo da construção. Sobre esse processo, além do depoimento de Antônio Baltar (jul. 1963), que trabalhou na equipe de Nunes, tem-se um relato do funcionamento da diretoria a partir da visita dos estudantes de engenharia ${ }^{18}$ e de medicina, ${ }^{19}$ quando a diretoria estava sob a responsabilidade de Fernando Saturnino de Brito, após o afastamento de Nunes para se tratar no Rio de Janeiro, de julho a setembro de 1937, quando faleceu. As visitas para conhecer 
as instalações, processos de trabalho e obras em andamento se deram em três etapas. A primeira etapa contou com a visita ao ateliê, onde eram elaborados desde os projetos de arquitetura e estrutura aos orçamentos. ${ }^{20}$ A segunda etapa contou com a visita à Seção de Controle (depósito de materiais), com a explicação dos "mecanismos de funcionamento da Diretoria" e "demonstração dos esforços que vêm sendo feitos em prol da racionalização dos seus métodos de trabalho" (Os alunos..., 29 jul. 1937). ${ }^{21} \mathrm{E}$ a terceira, com a visita às obras em execução, como o Pavilhão de Verificação de Óbitos, Instituto de Pesquisas Agronômicas, Reformatório de Menores, Pavilhão de Isolamento da Tamarineira e Escola para Anormais (Os alunos..., 29 jul. 1937).

A escola só foi concluída em 1956, não se sabe se seguindo o último projeto de Nunes, e, antes de ser demolida, na década de 1980, foi transformada numa Associação de Pais e Amigos dos Excepcionais (Apae), em 1964. São muitas incertezas quanto ao que resultou de seu projeto, inclusive se Cícero Dias, convidado a "decorar internamente a Escola de Anormais", chegou a realizar algum trabalho (Escola..., 6 dez. 1934).

Assim, nem Ulisses Pernambucano a viu pronta, pois em 1935 foi preso, aposentado compulsoriamente e afastado do serviço público, acusado de ser comunista, falecendo em 1943, aos 51 anos; nem Nunes, que faleceu em setembro de 1937, aos 29 anos, embora, mesmo afastado desde julho do mesmo ano, ainda estivesse vinculado à Diretoria de Arquitetura e Urbanismo de Pernambuco.

Além de iniciar o processo de trabalho que desenvolveu na diretoria, que ia dos projetos ao canteiro de obras, a ideia de fazer da Escola para Anormais um hospital-escola era uma inovação na concepção desse tipo de instituição. Outra contribuição importante aconteceu no projeto de um hospital-geral, o Hospital da Brigada Militar, como será visto no próximo tópico.

\section{O projeto do hospital-geral}

O projeto do Hospital da Brigada Militar visava atender a uma antiga demanda da corporação da polícia militar de Pernambuco por assistência à saúde. De acordo com registros que constam dos arquivos da Polícia Militar, citados pelo coronel Jorge Luís de Moura, a assistência médica aos militares contava em 1900 com dois médicos e, entre 1916 e 1919, com uma sala no Hospital Pedro II, para atendimento e internação dos militares, que "recebiam o mesmo tratamento dos indigentes e pagando a etapa, inexistindo na Força Pública, enfermaria, farmácia e ambulância" (Moura, 2010, p.1). A partir de 1929, a assistência médica passou a contar com um pequeno hospital, o Hospital Militar da Força Pública, instalado num edifício de dois pavimentos, em terreno próximo ao $2^{\circ}$ Batalhão da Força Pública, atual Quartel do Comando Geral da Polícia Militar, no Derby. Além do atendimento no Hospital da Força Pública, os militares também eram atendidos no Hospital Pedro II, no Hospital Santo Amaro e no Hospital de Doenças Nervosas e Mentais.

A construção do hospital fazia parte de um plano em que seriam oferecidos, junto ao então $2^{\circ}$ Batalhão da Força Pública, equipamentos como: campo de futebol, quadras de tênis, cinema, além do hospital (na Figura 8, consta a locação do hospital relativa aos 
equipamentos existentes e propostos). A apresentação da maquete do projeto aconteceu no Dia do Soldado, 25 de agosto de 1934, no evento em que foi colocada a pedra fundamental da construção e foram inaugurados um pavilhão sanitário e uma estação radiotelegráfica no quartel do Derby. O hospital foi inaugurado em 1941 (Figura 9).

\section{Figura 8: Projeto do Hospital da Brigada Militar}

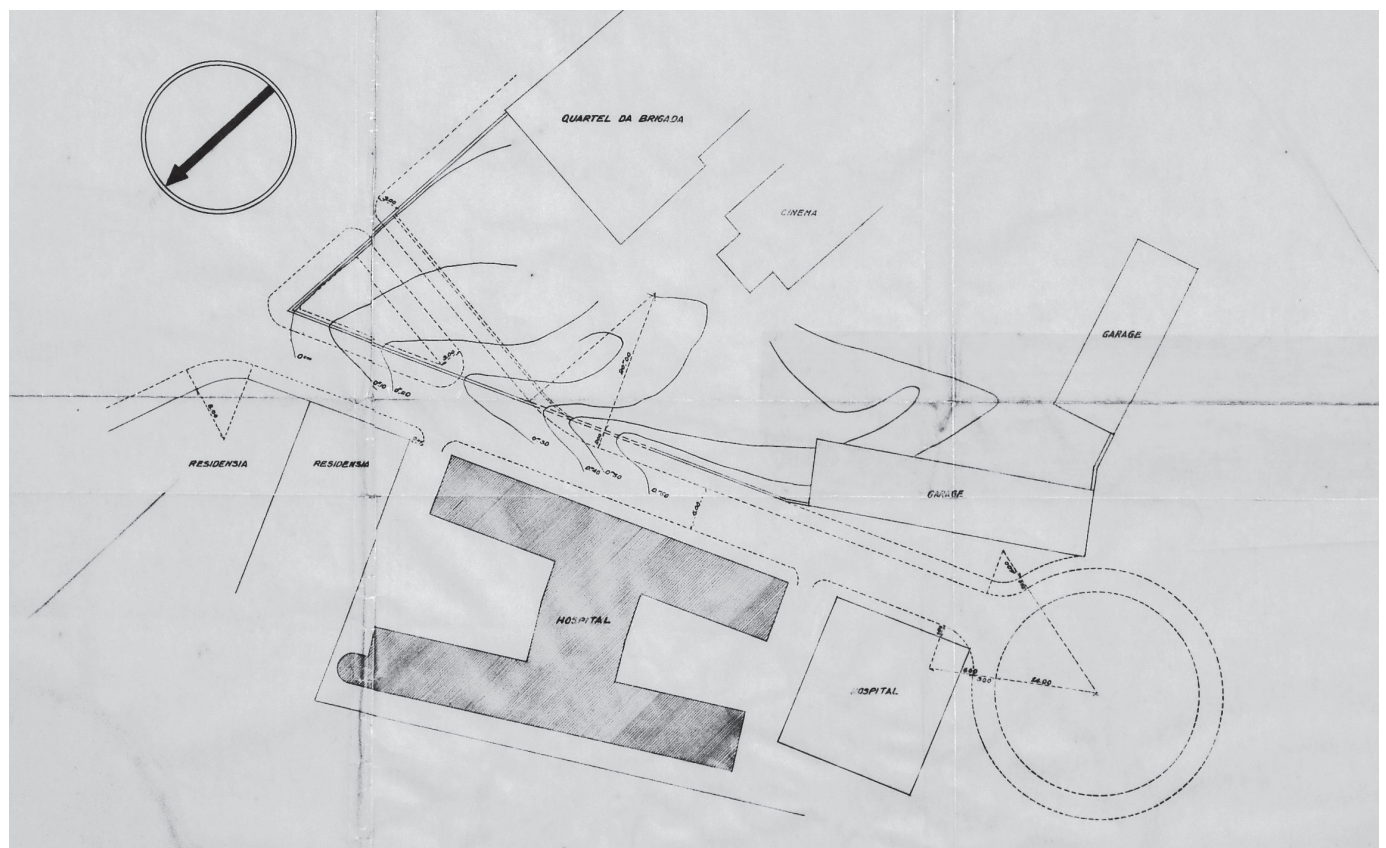

Fonte: Arquivo Público Jordão Emerenciano, Recife.

Figura 9: Hospital da Brigada Militar, em 1980

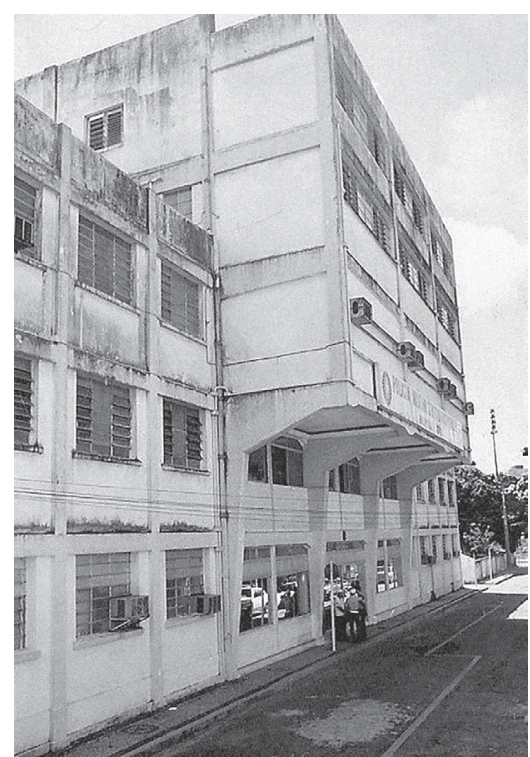

Fonte: Fundação do Patrimônio Histórico e Artístico de Pernambuco, Recife. 
Os projetos do Hospital da Brigada Militar, disponíveis para consulta no Arquivo Público Jordão Emerenciano, contam com uma versão de agosto de 1934 e outras, relativas a alterações da sua planta, com datas de 1935, 1936 e 1937. Como as obras foram iniciadas já em 1934, deduz-se que o projeto foi modificado no decorrer da construção, embora não fique claro o que teria motivado essas alterações. Não houve mudança substancial na sua setorização, mas nos arranjos espaciais dos seus setores, como ambulatório e centro de operações (cirúrgico).

A forma do hospital, dois blocos (paralelepípedos) não paralelos ligados por outro transversal e sobreposto formando um " $\mathrm{H}$ ", era uma inovação no projeto hospitalar promovida pelos EUA e ainda pouco divulgada no país, a da construção em monobloco. Segundo a classificação de Costa (2011a), o hospital se enquadraria em um monobloco modernista em forma de "H", que diferia do sistema pavilhonar, quanto à forma, ao uso (setorização) e à circulação (vertical e horizontal separada por tipos de usos); bem como diferia do monobloco de transição, caracterizado por manter linhas do art déco em sua composição de fachada.

A difusão desse novo tipo no Brasil foi marcada pela atuação da Divisão de Organização Hospitalar (DOH), do Ministério de Educação e Saúde, nos anos 1940, por meio de cursos, publicações e da consultoria e elaboração de projetos para novos hospitais. No entanto, de maneira pontual, com a expansão das atividades da Fundação Rockefeller na década de 1920, já era promovida a circulação de ideias e experiências de projetos de hospitais americanos, principalmente em São Paulo, onde teve por interlocutor o engenheiro e médico Ernesto de Sousa Campos. Para Costa (2011b, p.35), a mudança de paradigma entre o tipo pavilhonar e o monobloco teve como marco a mudança no projeto da Faculdade de Medicina e Cirurgia de São Paulo, em 1931, "sob orientação" da Fundação Rockefeller.

Das diferenças entre as propostas para o Hospital da Brigada de 1934 e 1937, ressalta-se que o volume resultante da proposta final é mais leve, com o balanço de dois pavimentos que marca a entrada principal do edifício. Além disso, a estrutura independente passou a ser valorizada na composição das fachadas, com a marcação das vigas e pilares e chanfros no encontro desses, junto às janelas em básculas de ferro e vidro (ver Figuras 10 e 11, relativas às perspectivas da primeira proposta, e Figura 12, relativa à segunda).

Figura 10: Projeto do Hospital da Brigada Militar

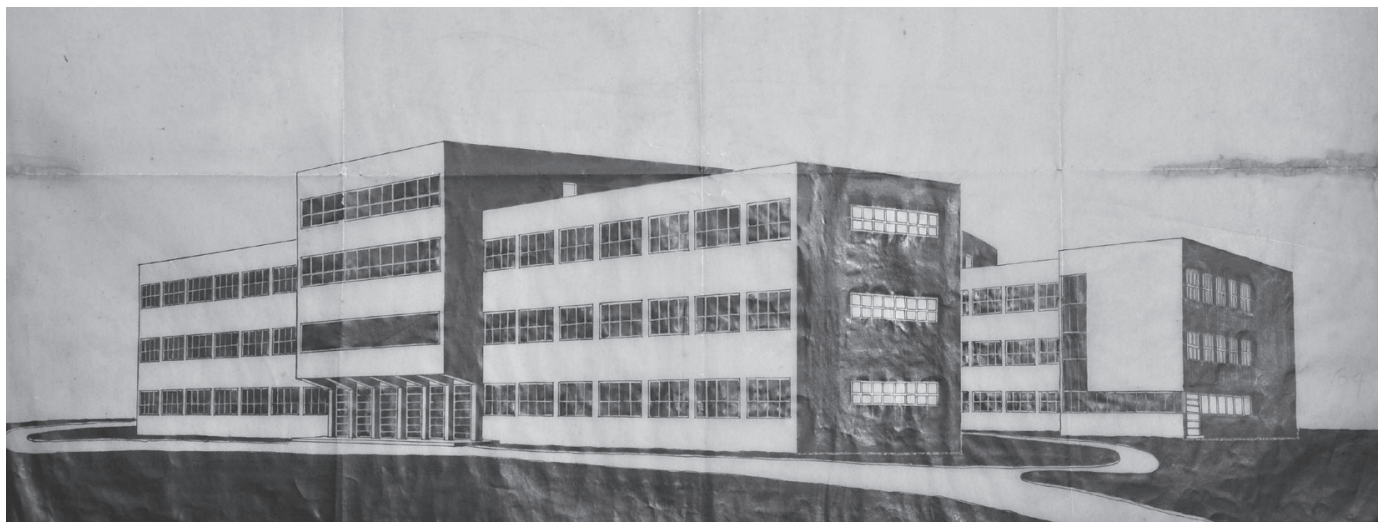

Fonte: Arquivo Público Jordão Emerenciano, Recife. 
Figura 11: Projeto do Hospital da Brigada Militar

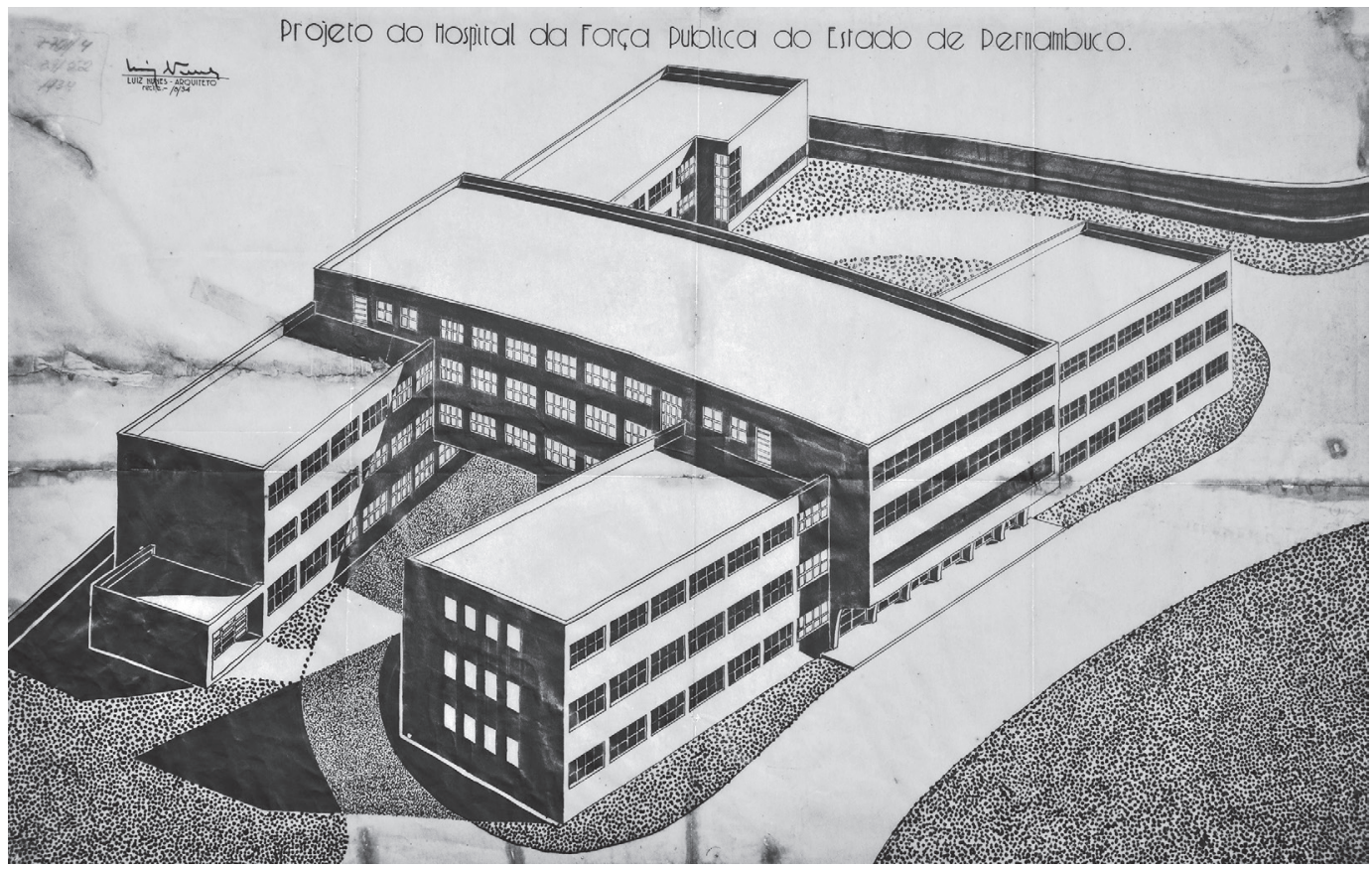

Fonte: Arquivo Público Jordão Emerenciano, Recife.

Figura 12: Projeto do Hospital da Brigada Militar

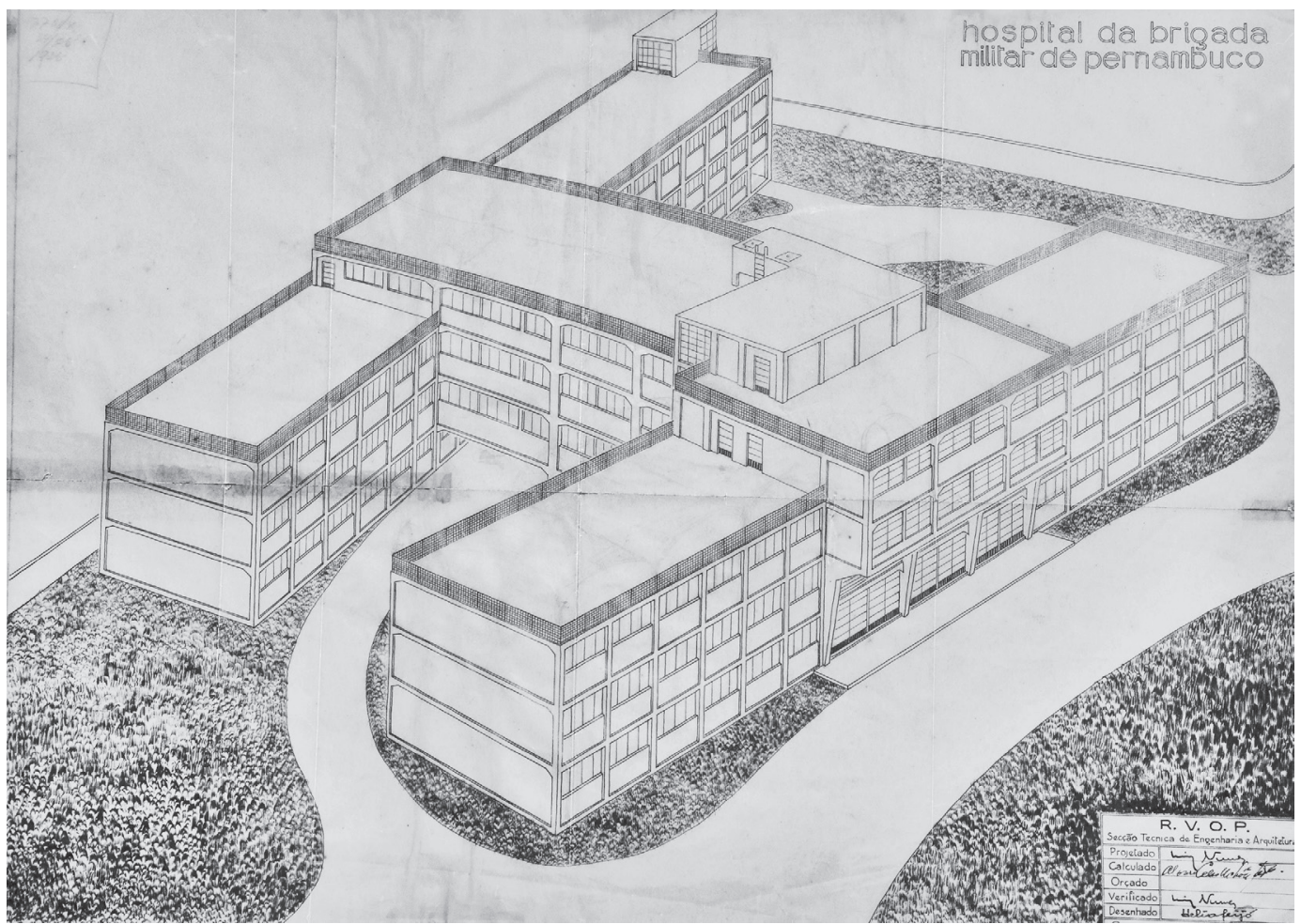

Fonte: Arquivo Público Jordão Emerenciano, Recife. 
Os acessos ao hospital foram separados, sendo o principal pela rua Betânia (em frente à praça Fernando Pessoa) e, pela mesma rua (em frente ao rio Capibaribe), mais quatro, dois para os ambulatórios, pelos fundos do bloco principal, dois pelo "túnel", para as ambulâncias e a admissão (roupa, plantão e banheiro), além de outro, para o almoxarifado, que não se conectava com o restante do edifício. A circulação vertical no bloco principal contava com uma escada e dois elevadores e, no bloco posterior, com mais duas escadas e os monta-cargas (para lixo, roupas limpas, roupas sujas, pratos). Esses elementos de circulação ficaram concentrados na área central do hospital, com excessão de uma escada, localizada na extremidade leste do bloco posterior, no setor de ambulatório e diagnóstico, o que, segundo o engenheiro Joaquim Cardozo (jul. 1963, p.13), era uma inovação, pois "foram empregadas, pela primeira vez, escadas de forma helicoidal só apoiadas nas extremidades".

No térreo, além de ambulatório (consultas e laboratórios), arquivo, contabilidade, fichário e admissão, constavam os serviços (lavanderia, cozinha, copa e refeitório). No segundo pavimento ficavam enfermarias e quartos, sala de médicos e refeitório. No terceiro pavimento, constavam as salas de operações séptica e antisséptica, enfermarias e quartos. No lado leste do bloco posterior constava o setor de clínicas e diagnósticos, que ia do térreo ao terceiro pavimento, com a escada de acesso. No quarto pavimento localizavavam-se somente enfermarias, quartos e área de isolamento de pacientes e mais quatro terraços.

Há assim, no térreo, em relação à primeira proposta, um acréscimo na estrutura da admissão (plantão e vestiário, além do banheiro), o deslocamento da contadoria para perto do arquivo, o acréscimo do almoxarifado não integrado aos outros ambientes, que sai do bloco posterior para o principal. Houve também um novo arranjo para os elevadores, sendo o maior deles para maca. No bloco posterior (dos fundos), a diferença entre a primeira e a última proposta é maior. A morgue (lugar para os cadáveres) deixa de fazer parte do corpo do edifício, embora não haja registro, tendo sido, talvez, relocada para alguma edícola no terreno. Os monta-cargas e as duas escadas foram mudados de posição, estas últimas também de forma, sendo que a dos ambulatórios, como já mencionado, adquire destaque no volume. Nesse bloco, os serviços de lavanderia, cozinha e refeitório e o ambulatório (consultas e exames) foram ampliados na última proposta (ver Figuras 13 e 14, relativas às plantas-baixas do térreo na primeira e na segunda versão). 
Figura 13: Projeto do Hospital da Brigada Militar

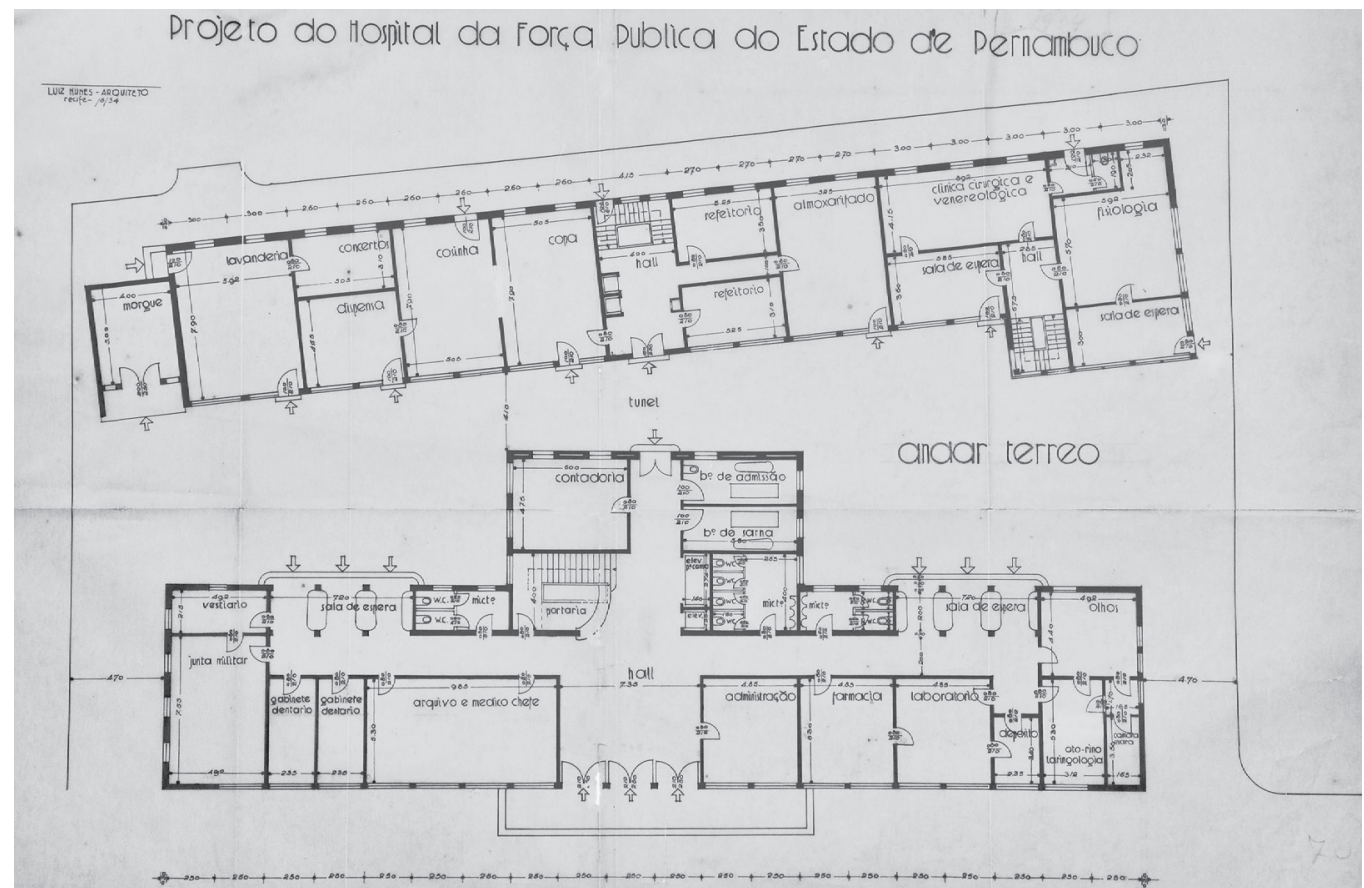

Fonte: Arquivo Público Jordão Emerenciano, Recife.

Figura 14: Projeto do Hospital da Brigada Militar

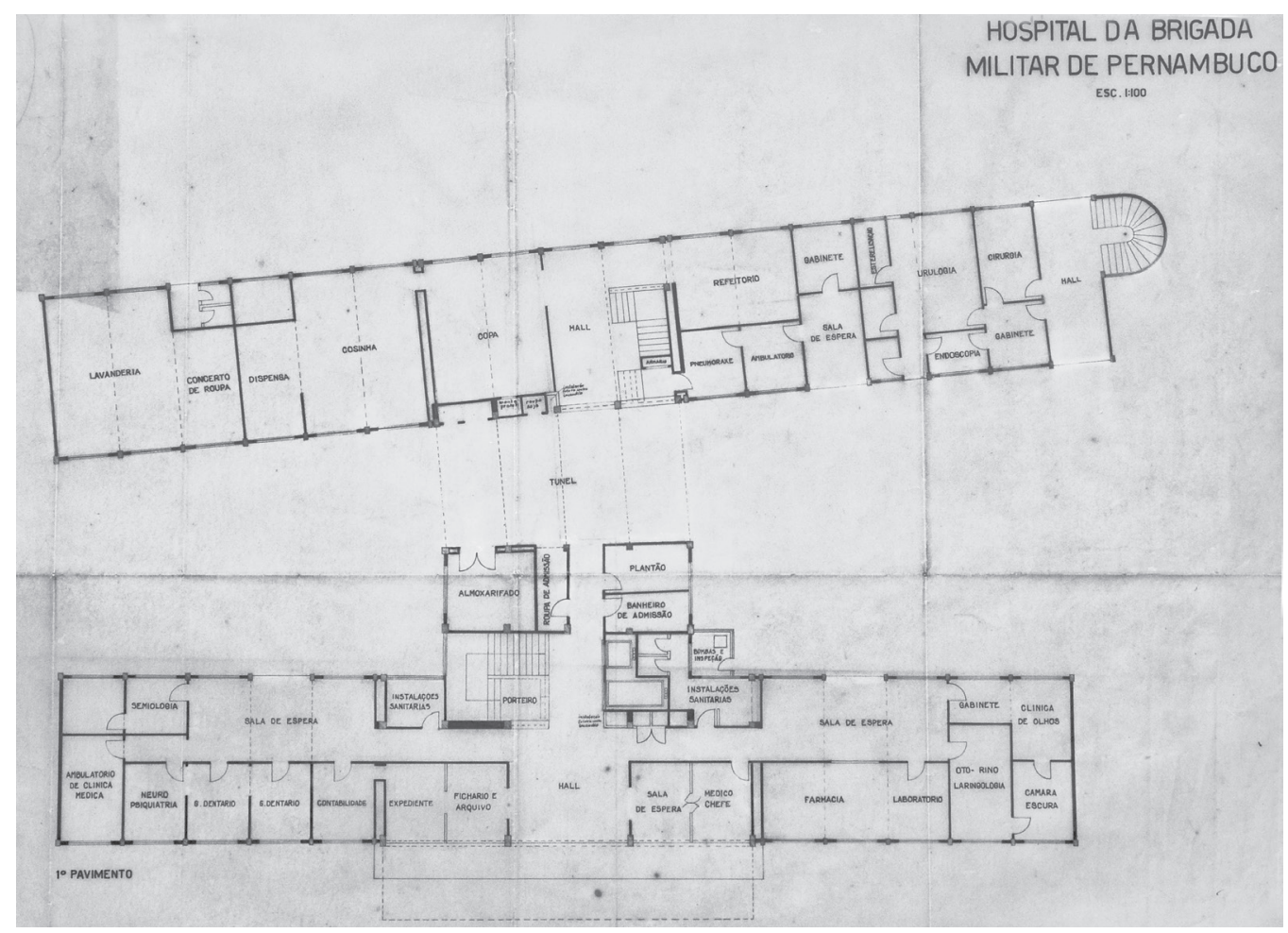

Fonte: Arquivo Público Jordão Emerenciano, Recife. 
O segundo pavimento/primeiro andar foi destinado ao internamento em enfermarias e quartos e ao apoio necessário, como quartos para médicos, enfermeiros (controle), sala de espera, banheiros. A diferença entre os projetos, desde 1934, ficou em seus arranjos espaciais, pois passou a haver mais uniformização das enfermarias e quartos, antes divididas por tipos de doenças: internas, doenças de pele, doenças venéreas, ou por grupo social, para sargento, moribundo, oficial, interno. Essa diferenciação estava também nos banheiros: para internos e médicos, praças e sargentos. A mudança maior entre as propostas original e a final foi a do corredor de circulação do bloco posterior, de uma face para outra do volume, e a separação da parte do ambulatório, que passa a funcionar de modo independente, perpassa todos os pavimentos e fica mais integrado ao restante do hospital após a supressão da porta de separação.

No terceiro pavimento/segundo andar, que abriga as salas de operações (cirurgia), houve uma série de estudos de arranjos espaciais. Em cada uma das quatro plantas consultadas relativas ao pavimento, há um arranjo diferente, além disso, há também um estudo mais detalhado do setor em separado na escala $1 / 50$, revelando, assim, a dificuldade de organizar esse espaço, que se especializava e exigia um ritual de preparo, assepsia, que ainda era pouco dominado (Figura 15).

Figura 15: Detalhe do projeto do Hospital da Brigada Militar

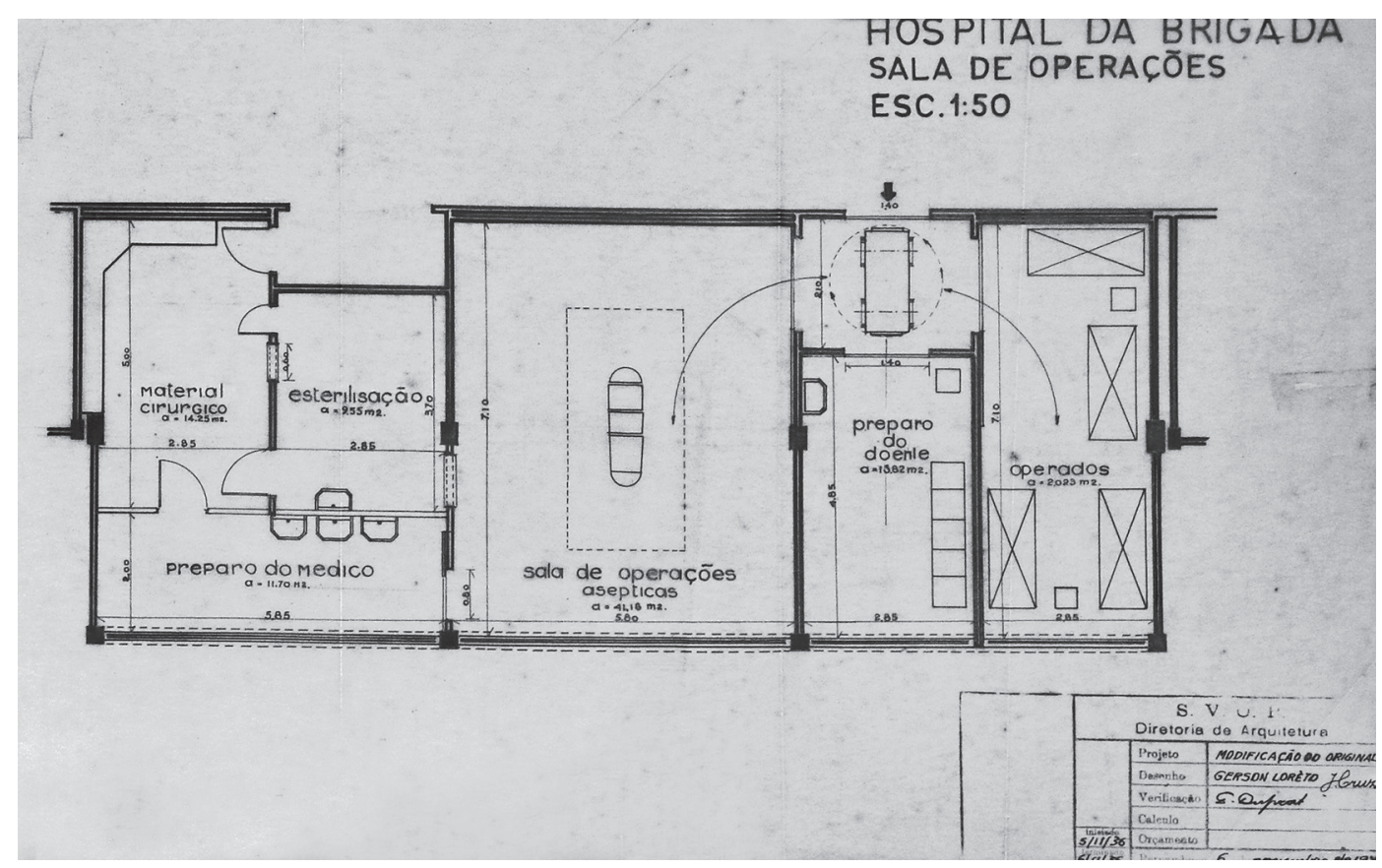

Fonte: Arquivo Público Jordão Emerenciano, Recife.

No quarto pavimento/terceiro e último andar, havia enfermarias e quartos de isolamento, prisão e quatro terraços. O isolamento também apresenta diferença em seu arranjo espacial, que passou a ter uma profundidade maior do que as outras enfermarias e mais independência, pois também passou a ter cozinha e copa. 
Percebe-se no projeto do Hospital da Brigada uma solução mais sofisticada do que a do projeto do hospital-geral, elaborado pela equipe de Nunes para a cidade de Escada e assinado pelo arquiteto e por Joaquim Cardozo, mas que, mesmo sendo um hospital de pequeno porte, apresenta em sua composição um volume formado por blocos articulados, não simétricos, uma preocupação em localizar a sua sala de operações num espaço mais profundo e menos acessível e uma setorização de suas atividades. Além de dois acessos distintos, o principal e o de serviços (Figura 16).

\section{Figura 16: Projeto do Hospital de Escada}

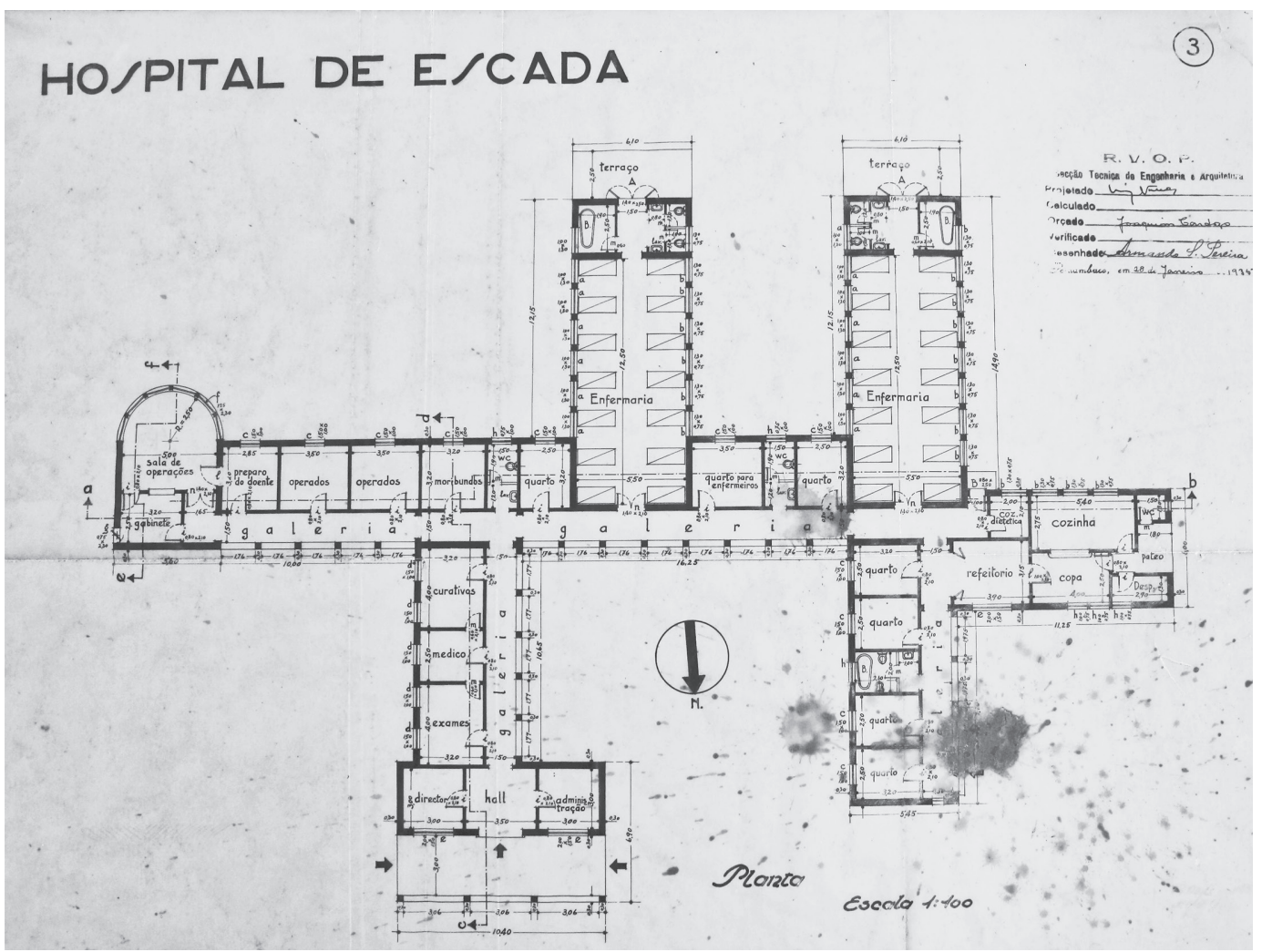

Fonte: Arquivo Público Jordão Emerenciano, Recife.

A construção do hospital para atender a uma corporação era um compromisso do governo de Carlos de Lima Cavalcanti firmado e iniciado antes de sua eleição em 1935. Em sua execução teve uma participação direta da tropa, como aponta Luiz Nunes (jul. 1963, p.19): "Com exceção dos capatazes todo o corpo operário é constituído por soldados, com redução de custo, formação de operários-soldados, devidamente especializados". Abaixo, a transcrição da exaltação feita ao soldado, quando fica claro o intituito de valorizar a profissão e o trabalho desses profissionais, e até mesmo premiá-los pelo apoio dado ao governo nos momentos de tensão política:

Quem se der ao trabalho de ir ao Derby com o senso de observação constatará a confortadora verdade de um novo sentido à vida da caserna. 
O soldado aí tem ambiente e tem vida.

Apresentam-se as obras do cinema já nas últimas demãos. Cinema dedicado ao duplo fim de recreiar e de educar. Naquela tela serão passados filmes apropriados à formação moral do soldado, oferecendo-lhe, ao mesmo tempo, conhecimentos úteis e gerais.

Mas, o trabalho de maior vulto que, atualmente, o governo realiza ali é, sem dúvida, o 'Hospital da Brigada'. Velha aspiração que se concretiza.

Melhor do que as palavras as fotografias mostram o valor da realização: um edifício monumental, de linhas arquitetônicas moderníssimas, de bela fisionomia, distribuídas as suas dependencias em três andares, para oitenta leitos, além das necessárias instalações indispensáveis a um nosocômio modelo.

Surpreendemos, ontem, os trabalhos em plena atividade. Executam-nos os próprios soldados, o que representa uma sensível economia para o erário pelo barateamento da mão de obra (A obra..., 21 maio 1935). ${ }^{22}$

Em maio de 1937, Lima Cavalcanti passou a ser acusado de tramar, trair e conspirar contra o governo de Getúlio Vargas. A construção do Hospital da Brigada Militar foi associada a uma possível corrupção e desvio de verba pelo governo estadual, o que foi respondido por Lima Cavalcanti como sendo, a acusação, parte de uma conspiração para derrubá-lo, orquestrada por Agamenon Magalhães, seu antigo aliado e, na época, ministro do Trabalho, Indústria e Comércio, por indicação sua. Lima Cavalcanti foi afastado do governo, logo após a decretação do Estado Novo em novembro de 1937 e, em 1938, aceitou a Embaixada da Colômbia, permanecendo fora do país até 1945 .

É importante destacar que, com a crise do governo, a diretoria e Luiz Nunes foram usados para atacar Lima Cavalcanti em editoriais no Diário de Pernambuco. Eram citadas a "inutilidade" da diretoria (Carlos..., 20 jul. 1937), chamada também de "escandalosa", (O aumento..., 10 set. 1937), "seio de Abrahão das repartições públicas" (O governo..., 11 set. 1937) e "departamento do luxo e do favoritismo" (Escandaloso!, 18 set. 1937) por conta de seus gastos. E Nunes, além de ser acusado de ser um "comunista notório" (Carlos..., 20 jul. 1937), foi também criticado por ser um sujeto estranho às elites locais, tal como consta na citação abaixo:

Procedem as justificativas oficiais? Ninguém de boa-fé dirá que sim, quando o sr. Carlos de Lima Cavalcanti, que as alega, aumenta incessantemente as despesas públicas, esbanjando os orçamentos em gastos supérfluos, em encenações administrativas, em banquetes, nas palhaçadas do sr. Paulo Carneiro ou na arquitetura (?) soviética do sr. Luiz Nunes. Se o tesouro está vazio, não obstante as maiores arrecadações orçamentarias até agora conseguidas por qualquer governo pernambucano, além dos auxílios e empréstimos de toda ordem postos à disposição do sr. Carlos de Lima, como justificar-se que Pernambuco, Estado de economia paupérrima possa gastar seiscentos e tantos contos de réis, apenas com o luxo do Palácio das Princesas - verba que somente uma ou duas das grandes unidades da Federação podem dispender com os chefes do Executivo? Como admitir-se que Pernambuco, o que não acontece com 98 por cento dos Estados brasileiros, possa manter inacreditável perdularismo de uma Diretoria de Arquitetura, quando a nossa administração só constrói um prediozinho mais vistoso de quatro ou de dez em dez anos?

Se o Estado anda em regime de falência, como admitir-se que o Tesouro pague, integralmente, a dois governadores, o que viaja e o que ocupa eventualmente o Campo 
das Princesas, onde o nosso preclaro e altissonante padre Felix Barreto assina de cruz o expediente e passeia, majestoso, nos assentos plebeus de um carrinho Ford ordinário? Se o Estado não tem dinheiro, como justificar-se o contrato, com a própria empresa jornalística do governador, para a publicação de livros oficiais luxuosos, que chegam a custar 43 contos por uma modesta edição de mil exemplares.

Se fosse sincero o sr. Carlos de Lima Cavalcanti, o aumento seria levado a efeito com o corte severo das despesas perdulárias e inúteis. E é preciso mesmo, não esquecer que ele tem favorecido a determinados funcionários, em detrimento da imensa maioria do funcionalismo público. O sr. Luiz Nunes, da célebre Diretoria de Arquitetura, e que há um mês anda passeando pelas avenidas cariocas, é um desses privilegiados, com a agravante de ser pessoa inteiramente estranha a Pernambuco, importado sem qualquer título honesto que justificasse a importação... (O governo..., 11 set. 1937).

Depois de construído, o hospital passou por uma série de reformas e ampliações. ${ }^{23}$ Destaca-se que a sua implantação, próxima ao quartel, tinha como vizinho o Hospital Militar da Força Pública, demolido nos anos 1960 para dar lugar à maternidade e ao hospital infantil, que foram construídos de modo contíguo ao Hospital da Brigada, fazendo com que este perdesse a sua forma original em " $\mathrm{H}$ ". Alterações, acréscimos e reformas em seu edifício original para a ampliação dos seus serviços ocasionaram sua descaracterização, apesar de haver em seu entorno áreas livres, ou que poderiam ser adensadas, e de, no seu interior, haver áreas subutilizadas. Além disso, o edifício original ganhou um pavimento a mais, no bloco lindeiro à rua de acesso principal e no bloco transversal, modificando ainda mais a proporção do seu conjunto.

Ao analisar o projeto do Hospital da Brigada Militar é possível compreender a importância da sua concepção para a história do projeto da arquitetura hospitalar, mesmo considerando que as ideias e os projetos do hospital americano já circulavam a partir dos investimentos feitos pela Fundação Rockefeller no país. No entanto, foi somente nos anos 1940 que essas ideias passaram a ter um alcance maior, dada a divulgação do DOH do Ministério da Educação e Saúde, do "hospital moderno", tal como tratato por Ribeiro (2016). Esse "hospital moderno" também seria um lugar de formação de um saber e do exercício do poder, com organização, circulação e distribuição dos indivíduos no espaço de acordo com os usos e funções, o que também foi pensado por Nunes no projeto da Escola para Anormais.

Em contexto favorável à recepção das ideias de Nunes no Recife, as obras analisadas se destacaram pela relação do saber médico, do projeto hospitalar moderno e da racionalidade formal. Essa junção fez com que a obra de Nunes se distinguisse entre os projetos de saúde contemporâneos aos seus em outras cidades brasileiras, como São Paulo, Rio de Janeiro e Salvador, que em sua maioria eram dominados pelas linhas art déco e, portanto, tiveram essa conjunção posteriormente aos projetos de Nunes. No Rio de Janeiro, Pedro Ernesto Batista, prefeito entre 1931 e 1934 e 1935 e 1936, promoveu um amplo programa educacional e de saúde, que incluiu a criação de hospitais, policlínicas e dispensários, que se caracterizavam pelas linhas art déco e, no caso dos hospitais, pelo atendimento aos princípios dos hospitais monobloco, como o Hospital Municipal Jesus, Hospital Policlínico (atual Hospital Universitário Pedro Ernesto) e Hospital Regional Periférico da Gávea (atual Hospital Miguel Couto) (Historia..., 2008). Em Salvador, teve destaque o projeto de Hypolito Gustavo Pujol Júnior e Ernesto de Sousa Campos para o Hospital das Clínicas, de 1938, 
considerado "monumental e híbrido em suas referências ao déco e à arquitetura moderna" (Andrade Júnior, 2011, p.128).

Essa racionalidade formal das obras de Nunes analisadas aqui tinha por referência, segundo Marques e Naslavsky (2011), a arquitetura moderna alemã de Walter Gropius e Mies van der Rohe. Só após 1936, com a segunda vinda de Le Corbusier ao Brasil e a sua participação no projeto do Ministério da Educação e Saúde, as ideias corbusianas foram mais bem assimiladas. Esse evento foi marcante tanto para o grupo carioca liderado por Lúcio Costa quanto para o de Nunes, no Recife, na segunda fase da sua produção.

\section{Considerações finais}

Na década de 1930, o Recife passava por uma série de discussões em torno de planos urbanísticos, ${ }^{24}$ que aconteciam de maneira desconectada das concepções de arquitetura desenvolvidas por Nunes e sua equipe. A localização dos equipamentos projetados por Nunes não eram orientadas por uma recomendação de que estivesse fora da área urbanizada, como aconteceu no século XIX, nem mesmo obedeciam a um plano que contemplasse a proximidade de vias de trânsito rápido ou a equidistância dos bairros, como aconteceu nas décadas de 1940 e 1950, quando a avenida Caxangá passou a ser uma via privilegiada de acesso aos edifícios hospitalares que eram criados: Hospital de Pronto-Socorro (atual Hospital da Restauração Governador Paulo Guerra), Hospital dos Usineiros (atual Hospital Barão de Lucena), Hospital do Iaptec (atual Hospital Getúlio Vargas), além do Hospital das Clínicas da Ufpe. As obras de Nunes e sua equipe atendiam a uma proximidade de outro serviço de saúde ou instituição a ele relacionada, o que determinava a sua localização.

A construção de um método de trabalho, iniciado com o projeto da Usina, culmina no projeto e construção da Escola para Anormais, revelando um modo de fazer, de pensar o edifício como um artefato, um constructo que deve ser concebido a partir da sua função, como instituição de saúde, e adaptado ao clima local. Além de ter promovido uma modernidade arquitetônica, relacionada a formas, espaços e estrutura, a criação da diretoria seria a aprovação e o coroamento de um trabalho iniciado por Nunes em meados de 1934 e que se revelou muito profícuo em relação à sua produção profissional, tendo sido estimulado pelo desejo político de Lima Cavalcanti de ser legitimado no cargo de governador na eleição de 1935.

\section{AGRADECIMENTOS}

A pesquisa que resultou neste artigo foi realizada com bolsa de Pós-doutorado Júnior do CNPq (2015-2017), supervisionada pelo professor Luiz Amorim.

\section{NOTAS}

${ }^{1}$ Luiz Carlos Nunes de Souza nasceu no Rio de Janeiro, em 1909, e faleceu na mesma cidade, aos 29 anos, em 23 de setembro de 1937. Casado, sem filhos, era filho de um capitão de mar e guerra, Joaquim Nunes de Souza. Colaboraram com o governo de Carlos de Lima, entre outros, intelectuais como Paulo Berredo Carneiro, Sílvio Grenville, Nélson Coutinho, Jansen de Melo, Aníbal Bruno e Ulisses Pernambucano. E, diretamente ligados a Nunes, trabalharam Roberto Burle Marx, Joaquim Cardozo e Antônio Bezerra Baltar, que se notabilizaram pelas contribuições ao campo do paisagismo, engenharia e urbanismo, respectivamente. 
${ }^{2}$ Melo (2000) analisou a obra de Luiz Nunes sob o ponto de vista da relação com o Estado.

${ }^{3}$ O Recife passou desde o início do século XX por intensa urbanização. Em 1900, a população era de 113.106 pessoas, em 1920, 238.843 pessoas e, em 1940, 348.424 pessoas. Em quarenta anos, mais do que triplicou a população, o que gerou uma sobrecarga em seus serviços de saúde e a necessidade de criar novas instituições.

${ }^{4}$ A sucessão entre os governadores de Pernambuco citados: Sérgio Loreto (1922-1926), Estácio Coimbra (1926-1930) e Carlos de Lima Cavalcanti (1930-1937).

${ }^{5}$ Durante o Estado Novo (1937-1945), Carlos de Lima Cavalcanti ficou fora do país à frente da embaixada brasileira da Colômbia e, depois, no México e em Cuba.

${ }^{6}$ Com o decreto, a Secretaria de Viação e Obras Públicas foi dividida em diretorias técnicas especializadas, entre elas a Diretoria de Arquitetura e Construções (DAC).

${ }^{7}$ Foram anunciadas também obras no porto, a construção do aeroporto, de um ginásio esportivo e da sede da Secretaria da Fazenda. Vale destacar que os planos urbanísticos eram conduzidos ou empreendidos pela prefeitura (Pernambuco..., 17 abr. 1935).

${ }^{8}$ Segundo Marques e Naslavsky (2011, p.1), "Efetivamente, a experiência e a presença de Joaquim Cardozo foram importantíssimas já na fase inicial dos trabalhos, tanto na interlocução profissional quanto na indicação de outros projetistas que também trabalhavam na linha de Le Corbusier".

${ }^{9}$ Em 13 de setembro de 1935, Nunes assumiu a Diretoria de Arquitetura e Construção, após uma demissão em 1936, foi recontratado em $1^{\circ}$ de dezembro de 1936, ficando vinculado até o seu falecimento em setembro de 1937 (Serviço..., 13 set. 1935, 1 dez. 1936).

${ }^{10} \mathrm{O}$ levantamento no Arquivo Público Jordão Emerenciano foi realizado pelas arquitetas Carolina Brasileiro e Patrícia Menezes como parte da pesquisa Patrimônio da Saúde em Pernambuco, fruto de convênio entre a Fundação Oswaldo Cruz e a Universidade Federal de Pernambuco.

${ }^{11}$ Comissão nomeada pelo ato n.845 (Vida..., 17 maio 1934).

${ }^{12}$ A saída de cena de Maia Neto da concepção dos principais projetos encampados pelo estado ainda precisa ser esclarecida. Sabe-se, no entanto, que o arquiteto-engenheiro partiu para a Alemanha em 12 de agosto de 1934, retornando em 21 de novembro do mesmo ano.

${ }^{13}$ Entre 1930 e 1931, o Departamento de Saúde e Assistência foi dirigido por Antonio Gonçalves de Lima. Com a reforma empreendida em 1931, a instituição passou a ser denominada Departamento de Saúde Pública, sendo dirigida por Jansen de Mello até 1932, quando foi substituído por Décio Parreiras, que ficou no cargo até o final de 1934. Quando a Casa da Criança foi inaugurada, o diretor do departamento era Necker Pinto.

${ }^{14}$ No Arquivo Público Jordão Emerenciano existem duas cópias de plantas, uma de 1934 e outra de 1937, absolutamente iguais, o que sugere que o seu projeto não foi modificado nem antes, nem ao longo de sua construção.

15 “O projeto implicava a inclusão de uma nova unidade entre as que compunham o Curso de Aplicação. Deste modo, as alunas concluintes - as professorandas - passariam a ter a oportunidade da prática necessária para trabalharem com crianças deficientes. Para ele, estava claro que a nova disciplina facilitaria às alunas enfrentar o exercício profissional futuro, ao identificarem crianças com dificuldades de aprendizagem, fossem as dificuldades devidas a algum grau de retardamento no seu desenvolvimento mental, a fatores emocionais ou a outros fatores perturbadores do comportamento" (Barreto, 1992, p.16).

${ }^{16}$ A Liga de Higiene Mental de Pernambuco surgiu de modo independente e não estava alinhada com a Liga Brasileira de Higiene Mental, criada em 1923.

${ }^{17}$ Foi idealizada inclusive uma campanha para a realização e concurso de cartazes para a divulgação da construção da Escola para Anormais entre desenhistas e pintores: "No cartaz deverão figurar os seguintes dizeres: 'Auxiliai a construção da Escola de Anormais'”. Logo, "Os trabalhos ser[iam] julgados por uma comissão de neuro-higienistas, membros da Liga" (Liga de Higiene..., 13 dez. 1934).

${ }^{18}$ A visita dos estudantes de engenharia ocorreu em 30 de julho de 1937.

${ }^{19}$ A visita dos estudantes de medicina ocorreu em 16 de setembro de 1937, intermediada pela Sociedade Acadêmica Médica. Destaca-se que o diretor da Faculdade de Medicina era Aggeu Magalhães, indicado por Carlos de Lima Cavalcanti e irmão de Agamenon Magalhães. As obras visitadas foram Hospital da Brigada Militar, Hospital de Alienados, Escola de Anormais, Reformatório de Menores. 
20 "O arquiteto Saturnino de Britto, chefe do atelier, apresentou aos visitantes, as coleções de plantas, desenhos de detalhes, orçamentos etc., que compõem cada projeto elaborado" ... "Na parte referente ao cálculo das estruturas de concreto armado o engenheiro Joaquim Cardozo, calculista da DAU chamou a atenção dos estudantes para os processos empregados em cada caso particular, alguns desses, os mais modernos que se conhecem e que permittiram obter dimensões extremamente reduzidas para as peças das construções" ... "Ainda no atelier, os professores e alunos da Escola de Engenharia entraram em contato com a organização dos serviços da Diretoria de Arquitetura, verificando o mecanismo de preenchimento das fichas diárias de produção do pessoal, a distribuição das ordens de serviço bem como verificação dos mesmos" (A visita..., 1 ago. 1937).

${ }^{21} \mathrm{Na}$ Seção de controle da DAU/Depósito de materiais (rua da Aurora) - chefiado por Napoleão de Albuquerque: "Em ligeira explanação foram indicadas as linhas gerais do plano de controle que vem sendo executado sobre as construções, plano que permite conhecer em cada instante os gastos até então realizados em cada obra bem como distribuição destes gastos pelos diferentes serviços de que a obra se compõe". Plano que sofre "aperfeiçoamento constante... no sentido de atingir ao máximo de eficiência pela elevação do operário de construção civil a um standard de trabalho mais elevado e racional. ... Os visitadores percorreram em seguida o depósito de materiais examinando os fichários de controle, de armazenagem e movimento de materiais bem como a coleta de dados para a organização do mapa de transportes da cidade do Recife" (A visita..., 1 ago. 1937).

22 "Os problemas de ordem pública exigiram do Governo Revolucionário medidas amplas e seguras, uma vez que a substituição violenta de um estado de coisas tornado indesejável naturalmente gerou descontentes que passaram a agitar-se, reunidos a outros portadores de princípios exagerados e a elementos que a Revolução de 1930 teve que afastar de si. Esse cuidado pedia garantia de tranquilidade da população, n’um período em que se fazia mister a implantação de severas economias, explica as transformações que o Governo Revolucionário teve que imprimir aos serviços de policiamento, transformando a antiga Repartição Central de Polícia em Delegacia Geral de Polícia, logo substituída por uma Secretaria de Segurança Publica, a cuja frente estiveram o coronel Jurandyr Mamede, o capitão Nelson de Mello e o capitão Rossini de Medeiros Raposo. [O decreto n.361, de 19 dez. 1934, sistematizou e regulamentou os diversos orgãos do policiamento]. ... Pode-se dizer que estão substituídas ou, pelo menos, profundamente remodeladas todas as instalações da polícia, desde os prédios até o mobiliário. Nada mais lastimável havia do que a localização das delegacias e dos comissariados mesmo da capital, funcionando em casas de nenhuma segurança e nenhum conforto" (Governo..., 5 maio 1935).

${ }^{23}$ Com a sua inauguração, sete anos depois de iniciada a construção, passaram a funcionar as clínicas médicas, neuropsiquiatria, doenças do aparelho respiratório, urologia, oftalmo e otorrinolaringologia, além de cirurgia, dentista, laboratório de análises, raio x, farmácia, as juntas militar e superior de saúde, socorro médico e serviço de assistência pré-natal e obstetrícia (Moura, 2010, p.2). A estrutura do hospital cresceu ao longo do tempo e passou a ocupar as áreas livres existentes e surgidas após desapropriações. Surgiram o Laboratório Semi-industrial (1957), para o fabrico de remédios; o Laboratório de Análises, o Serviço de Arquivo Médico e Estatística, a Maternidade e Hospital infantil (1967), a Diretoria e Divisão Administrativa e a Clínica de Neurologia (1972) e o Centro Odontológico (1979). Desde 1970, o hospital militar faz parte de um centro hospitalar, denominado Coronel Médico Dr. Guilherme Cirne de Azevedo, do qual fazem parte também a Maternidade Professor Fernando Simões Barbosa e o Hospital Infantil, que chegou a abrigar o serviço social e as clausuras das irmãs da Congregação de Sant'Ana, além de uma capela.

${ }^{24}$ Propostas de planos urbanísticos de Domingos Ferreira (1927), com propostas apenas para o bairro de Santo Antônio, Nestor Figueiredo (1932), Atílio Corrêa Lima (1936) e Ulhôa Cintra (1943).

\section{REFERÊNCIAS}

A CASA...

A Casa da Criança. Diário da Manhã, p.1, 3.9 ago. 1934 .

A CONSTRUÇÃO...

A construção do futuro edificio da Usina

Higienizadora de Leite. Diário da Manhã, p.1. 21 jun. 1934.

ALECRIM, Laura; AMORIM, Luiz.

A forma segue o leite ou o leite segue a forma?
Da arquitetura das usinas de pasteurização do Recife. Arquitextos, ano 11, n.121.00, p.1-12. Disponível em: <http://www.vitruvius.com.br/ revistas/read/arquitextos/11.121/3426>. Acesso em: 19 set. 2017. 2010.

AMORA, Ana.

O nacional e o moderno: arquitetura e saúde no Estado nas cidades catarinenses. Tese (Doutorado) - Instituto de Pesquisa e 
Planejamento Urbano e Regional, Universidade Federal do Rio de Janeiro, Rio de Janeiro. 2006.

ANDRADE JÚNIOR, Nivaldo Vieira de.

Arquitetura moderna e as instituições de saúde na Bahia nas décadas de 1930 a 1950. In: Souza, Christiane Maria Cruz de; Barreto, Maria Renilda Nery (Org.). História da saúde na Bahia: instituições e patrimônio arquitetônico (18081958). Barueri: Minha Editora. p.101-145. 2011.

A OBRA...

A obra de valorização do soldado pernambucano. Diário da Manhã, p.1. 21 maio 1935.

A VISITA...

A visita dos estudantes de engenharia à Diretoria de Arquitetura e Urbanismo. Diário da Manhã, p.6. 1 ago. 1937.

BALTAR, Antonio.

Luiz Nunes. Arquitetura, n.13, p.6-10. jul. 1963.

BARRETO, Anita Paes.

Ulisses Pernambucano, educador. Psicologia:

Ciência e Profissão, v.12, n.1, p.14-17.

Disponível em: <http://pepsic.bvsalud.org/

scielo.php?script $=$ sci_arttext $\&$ pid $=$ S1414-

$98931992000100003 \& \operatorname{lng}=$ pt\&nrm $=$ iso $>$.

Acesso em: 19 set 2017. 1992.

CARDOZO, Joaquim

Joaquim Cardoso e o DAU. Arquitetura, n.13, p.11-15. jul. 1963.

CARLOS...,

Carlos de Lima Cavalcanti, vesânico palavroso! Diário de Pernambuco, p.7. 20 jul. 1937.

COSTA, Renato Gama-Rosa.

Apontamentos para a arquitetura hospitalar no Brasil: entre o tradicional e o moderno. História, Ciências, Saúde - Manguinhos, v.18, supl.1, p.53-66. Disponível em: <http://www.scielo. br/scielo.php?script=sci_arttext\&pid=S010459702011000500004\&lng=en\&nrm=iso\&tlng= pt>. Acesso em: 19 set. 2017. 2011a.

COSTA, Renato Gama-Rosa.

Arquitetura hospitalar em São Paulo. In: Mott, Maria Lucia; Sanglard, Gisele (Org.). História da saúde em São Paulo: instituições e patrimônio arquitetônico (1808-1958). Barueri: Minha Editora. p.25-61. 2011b.

DIÁRIO...

Diário da Manhã, p.1. 22 jun. 1934.

DIRETORIA...

Diretoria de Arquitetura e Construção: uma escola para débeis mentais. Diário da Manhã, p.6. 24 nov. 1935.

\section{ESCANDALOSO!}

Escandaloso! Diário de Pernambuco, p.7. 18 set. 1937.
ESCOLA...

Escola de anormais. Diário da Manhã, p.1. 17 set. 1935.

ESCOLA...

Escola de Anormais. Diário de Pernambuco, p.6. 6 dez. 1934.

FALCÃO, Edgar.

Fazer o bem. Diário de Pernambuco, p.4. 24 nov. 1934.

FOI ONTEM...

Foi ontem colocada a pedra fundamental da Escola de Anormais. Diário de Pernambuco, p.5. 27 dez. 1934.

FOUCAULT, Michel.

O poder psiquiátrico. São Paulo: Martins Fontes. 1996.

GOVERNO...

Governo revolucionário de Pernambuco. Diário da Manhã, p.11. 5 maio 1935.

HISTORIA...

Historia y Patrimonio Cultural de la Salud.

Biblioteca Virtual en Salud: Historia y Patrimonio

Cultural de la Salud (BVS HPCS). Disponível em <http://patrimonioarquitetonico.coc.fiocruz.br/ cgi-bin/wxis.exe/iah/>. Acesso em: 18 fev. 2018. 2008.

INICIA-SE...

Inicia-se hoje, no Recife, a semana da criança anormal. Diário da Manhã, p.3. 24 maio 1936.

KOPP, Anatole.

Quando o moderno não era um estilo e sim uma causa. São Paulo: Nobel; Edusp. 1990.

LANÇAMENTO...

Lançamento da primeira pedra da Casa da Criança. Diário da Manhã, p.1, 11. 17 ago. 1934.

LIGA DE HIGIENE...

Liga de Higiene Mental de Pernambuco. Diário de Pernambuco, p.1. 11 jan. 1935.

LIGA DE HIGIENE...

Liga de Higiene Mental de Pernambuco. Diário da Manhã, p.1. 13 dez. 1934.

LIGA DE HIGIENE...

Liga de Higiene Mental de Pernambuco. Diário da Manhã, p.5. 16 out. 1934.

LIGA PERNAMBUCANA...

Liga Pernambucana Contra a Mortalidade Infantil. Diário da Manhã, p.5. 10 jun. 1936.

LIGA PERNAMBUCANA...

Liga Pernambucana Contra a Mortalidade Infantil. Diário da Manhã, p.1. 5 jul. 1934.

MARQUES, Sonia; NASLAVSKY, Guilah. Eu vi o modernismo nascer... foi no Recife. 
Arquitextos, ano 11, n.131.02, p.1-17. Disponível em: <http://www.vitruvius.com.br/revistas/ $\mathrm{read} /$ arquitextos/11.131/3826>. Acesso em: 19 set. 2017. 2011.

MEDEIROS, Amaury de.

Saúde e assistência: doutrinas, experiências e realizações, 1923-1926. Recife: [s.n]. 1926.

MELO, Alcínia Afonso de.

Revolução na arquitetura: Recife, década de trinta. Dissertação (Mestrado) - Programa de Pósgraduação em História, Universidade Federal de Pernambuco, Recife. 2000.

MOURA, Jorge Luiz de.

O sistema de saúde da PMPE. [s.l.: s.n.]. 2010.

NUNES, Luiz.

Uma diretoria de arquitetura. Arquitetura, n.13, p.16-20. jul. 1963.

O AUMENTO...

O aumento dos vencimentos do funcionalimo público. Diário de Pernambuco, p.7. 10 set. 1937.

O DIA...

O Dia da Criança Anormal. Diário de

Pernambuco, p.5. 20 dez. 1934.

O GOVERNO...

O governo escarnece do funcionalismo. Diário de Pernambuco, p.7. 11 set. 1937.

OS ALUNOS...

Os alunos da Escola de Engenharia de Pernambuco visitarão amanhã os serviços da Diretoria de Arquitetura e Urbanismo. Diário da Manhã, p.1. 29 jul. 1937.
PELA EDUCAÇÃO...

Pela educação da criança anormal. Diário de Pernambuco, p.5. 5 dez. 1934.

PERNAMBUCO...

Pernambuco sob o regime da lei: em entrevista coletiva aos jornalistas cariocas o governador Lima Cavalcanti expõe, em síntese, o seu plano administrativo. Diário da Manhã, p.1-6. 17 abr. 1935.

RIBEIRO, Cecilia.

"Sistematização! Padronização! Especialização!": o hospital-geral no Brasil nos anos de 1940. In: Seminário Nacional do Docomomo Brasil, 11., 2016, Recife. Anais... Recife: Docomomo Brasil. p.1-12. 2016.

\section{SERVIÇO...}

Serviço público. Diário de Pernambuco, p.5. 1 dez. 1936.

\section{SERVIÇO...}

Serviço público. Diário de Pernambuco, p.4. 13 set. 1935.

UMA VISITA...

Uma visita às obras da Escola de Anormais. Diário de Pernambuco, p.5. 17 set. 1935.

VIDA...

Vida administrativa. Diário da Manhã, p.4. 20 nov. 1934

VIDA...

Vida administrativa. Diário da Manhã, p.4. 17 maio 1934. 